\title{
POLITICAL BUSINESS CYCLES: EVIDÊNCIAS EMPÍRICAS PARA OS MUNICÍPIOS PAULISTAS $(1989$ - 2001)*
}

\author{
Sergio Naruhiko Sakurai ${ }^{\S}$ \\ Amaury Patrick Gremaud
}

\begin{abstract}
RESUMO
Este artigo analisa o comportamento fiscal dos municípios paulistas perante dois fatores de ordem política: o calendário eleitoral e os diferentes partidos políticos dos prefeitos municipais, entre os anos de 1989 e 2001. São analisados componentes específicos do orçamento público por meio de Econometria de dados em painel, sendo encontradas evidências de impulsos positivos na despesa municipal nos anos eleitorais de 1992 e 1996, ao passo que, no tocante às agremiações partidárias, observa-se que: (i) PFL é o partido que mais investe; (ii) PTB, PPB/PDS e PMDB são os partidos que mais despendem recursos em transferências correntes. Adicionalmente, a Lei de Responsabilidade Fiscal parece exercer influência significativa sobre o comportamento das despesas municipais.
\end{abstract}

Palavras-chave: ciclos políticos, dados em painel, finanças públicas municipais.

\begin{abstract}
This paper analyses the fiscal performance of the São Paulo state municipalities during the 1989-2001 period, considering the influence of two political factors: the electoral agenda and the different political party ideologies. By considering specific components of the public municipal budget and panel data Econometrics, evidences of positive impulses in municipal expenditures were found in the election years of 1992 and 1996 and, for the political parties, it is found evidences that: (i) higher public investments are undertaken by PFL; (ii) PTB, PPB/PDS and PMDB spend more financial resources in personal current transfers than the other political parties. Additionally, the Brazilian Fiscal Responsibility Law seems to exert an effective control on the public budget performance.
\end{abstract}

Key words: political cycles, panel data, public municipal budget.

JEL classification: H72, C23, P43.

\footnotetext{
* Este trabalho é resultado da dissertação de Mestrado do primeiro autor, sob orientação do segundo. Os autores agradecem o financiamento da Capes, bem como os comentários de Naercio Menezes-Filho, Reynaldo Fernandes, Fernando Postali, Marcos Gonçalves da Silva, Renata Narita e de dois pareceristas anônimos desta publicação. Quaisquer erros remanescentes são, certamente, de nossa inteira responsabilidade.

$\S$ Mestre e doutorando em Economia pelo IPE - FEA - USP. Endereço para contato: FEA/SP-USP: Av. Prof. Luciano Gualberto, 908 - Cidade Universitária - CEP: 05508-010 - São Paulo - SP. E-mail: sakurai@usp.br.

a Departamento de Economia - FEA/RP - USP. E-mail: agremaud@usp.br.

Recebido em janeiro de 2005. Aprovado em março de 2007.
} 


\section{INTRODUÇÃO E JUSTIFICATIVA}

Poucos indivíduos assumiriam posição contrária à idéia de que fatores (e resultados) de ordem política e fatores (e resultados) de ordem econômica caminharam, e provavelmente sempre o farão, de maneira conjunta, sendo praticamente indistinguível a relação de causalidade entre si. Consente-se que a permanência no poder de determinado governante está condicionada aos resultados advindos de suas próprias ações e, levando em consideração a existência dos eleitores e dos políticos, é razoável considerar que a divergência de interesses tanto entre grupos como intragrupos pode alterar o processo de decisão política e, por conseqüência, a alocação dos recursos públicos (ineficiência ou distorção alocativa).

Pode-se definir, de maneira simplificada, os ciclos políticos como sendo a sensibilidade das variáveis econômicas perante fatores de ordem política, ou seja, fatores associados ao ambiente político influenciando o comportamento da economia. Em relação aos políticos, pode-se considerar a hipótese da existência de um incentivo ao governante para que este promova alterações de política econômica, visando elevar sua probabilidade de permanência no poder, ou então, se a probabilidade de reeleição do policymaker (ou de outro candidato de seu partido) é reduzida, pode existir um incentivo para que este distorça sua política econômica em seu último período de governo, visando prejudicar o governo do próximo administrador. Tais fatores poderiam gerar os denominados "ciclos eleitorais", ou seja, a sensibilidade das variáveis econômicas ante a vigência do calendário eleitoral. Já em relação aos partidos políticos, pode-se considerar a hipótese de que, caso exista um mínimo de consistência ideológica por parte destes e caso haja uma constante alternância no poder entre os mesmos, então a implementação de políticas de gestão pública estaria suscetível aos denominados "ciclos partidários”, ou seja, flutuações econômicas associadas às diferenças de postura dos partidos políticos. Como conseqüência, políticas de caráter de longo prazo (e provavelmente as de curto prazo também) poderiam apresentar aplicabilidade e retornos limitados.

Neste contexto, a análise do comportamento fiscal ${ }^{1}$ dos municípios brasileiros torna-se relevante, tanto pela importância que estas instâncias do poder político desempenham no bem-estar dos indivíduos como pela ausência, na literatura brasileira, de estudos que promovam a análise da interação entre elementos de ordem econômica e elementos de ordem política em tais localidades. Deve-se considerar também a relevância dos municípios brasileiros pelo fato de que, em regimes descentralizados do poder político (que vem a ser o caso brasileiro), a maior parte dos bens públicos é ofertada justamente pelos Estados e municípios. Já em particular, no caso dos policymakers, é razoável considerar também que seu sucesso e ascensão no cenário político nacional muitas vezes estão condicionados ao sucesso que estes obtêm na administração de instâncias menos agregadas do poder político, o que reforça ainda mais a importância da análise do comportamento fiscal dos municípios brasileiros e sua relação com fatores de ordem política. Assim, se tais hipóteses são verdadeiras, pode ser maior a probabilidade de que o comportamento destes níveis do poder político esteja sujeito a alguma ciclicidade política, seja ela de natureza oportunista ou partidária. Por fim, um último fator relevante a ser considerado no caso brasileiro é o caráter exógeno do calendário eleitoral, o que pode permitir à classe política ajustar o timing das políticas implementadas, de modo que os resultados obtidos possam ser posteriormente vinculados a uma maior popularidade do mesmo e, conseqüentemente, a uma maior probabilidade de permanência no poder.

Tendo tais elementos em mente, o objetivo deste trabalho é avaliar se o comportamento das despesas dos municípios paulistas está sujeito a fatores de ordem política, levando em consideração a vigência do calendário das eleições municipais e a postura dos partidos políticos que governaram

1 Como bem aponta Drazen (2002), políticas fiscais são relevantes neste contexto político dado que as mesmas sempre geram resultados econômicos de ordem real, ao contrário de políticas monetárias. 
tais instâncias administrativas, entre os anos de 1989 e 2001. O presente trabalho está dividido em quatro seções, além desta breve introdução ao tema. Na segunda seção, será apresentada uma breve revisão da literatura internacional e nacional. Na terceira seção, são apresentadas as hipóteses que norteiam este estudo, bem como o modelo econométrico a ser estimado. Na quarta seção, constam a apresentação e a análise dos resultados obtidos nas estimações e, por fim, na quinta seção, são apresentados os resultados gerais e as considerações finais.

\section{EXISTÊNCIA DOS CICLOS POLÍTICOS: REFERÊNCIAS BÁSICAS}

A linha de pesquisa intitulada por Romer (2001) New political economy considera como elemento importante na análise econômica a interação entre a teoria econômica e elementos da teoria política. Entre estes fatores fundamentais para a existência dos ciclos políticos, as análises são embasadas na existência de alguma forma de incentivo, sejam eles incentivos oportunistas ou incentivos partidários.

De acordo com a escola de análise relacionada à existência de incentivos oportunistas, os ciclos políticos podem ser vistos como sendo resultados de ações promovidas pelo governante para obter uma maior probabilidade de reeleição, independente de ideologia partidária. Entre os trabalhos considerados fundamentais, pode-se citar Nordhaus (1975), em que é considerado o pressuposto de que os eleitores, apesar de racionais em suas preferências acerca da condução da economia, desenvolvem suas expectativas de forma adaptativa. Por sua vez, pode-se considerar os trabalhos de Rogoff e Sibert (1988) e Rogoff (1990) como principais marcos na análise dos ciclos eleitorais considerando indivíduos racionais, mas atuando em um ambiente de informação imperfeita. Por outro lado, no que diz respeito à corrente literária dos incentivos (ciclos) partidários, que pode ser vista como uma espécie de contraponto à teoria dos ciclos eleitorais, pode-se considerar como principais trabalhos os realizados por Hibbs (1977), nos quais também é considerado o pressuposto de expectativas adaptativas, e o trabalho realizado por Alesina (1987), no qual também passa a ser incorporado o pressuposto de indivíduos racionais atuando em um ambiente de informação imperfeita. De acordo com ambas as teorias, associam-se as flutuações econômicas às diferentes ideologias políticas dos partidos dos governantes.

Conforme sugere Rogoff (1990), alguns autores analisam a presença de ciclos políticos em níveis menos concentrados de governo. Um estudo que pode ser considerado relevante neste contexto é o trabalho de Petterson-Lidbom (2001), cujo objetivo se assemelha à nossa proposta, primeiro por considerar o comportamento fiscal das mesmas entidades da Federação (no caso, os municípios suecos); segundo por utilizar uma alternativa de tratamento bastante semelhante (por meio também de uma abordagem econométrica do tipo dados em painel); terceiro pela semelhança do calendário das eleições municipais suecas, sendo as mesmas realizadas periodicamente a cada quatro anos, da mesma forma que no caso brasileiro.

$\mathrm{O}$ autor estima uma forma funcional em que é relacionado o volume de despesas em função de uma dummy indicando ano eleitoral, em função da proporção de jovens e de idosos na população, tamanho da população, renda per capita, densidade populacional, crescimento do PIB e receita de transferências governamentais. São obtidos resultados estatisticamente significantes para a dummy de ano eleitoral, sugerindo um maior volume de recursos gastos nestes anos. São observados também coeficientes significativos para todos os regressores (à exceção das transferências), sendo que uma maior proporção de idosos e jovens, bem como uma maior renda per capita implicam um maior volume de gastos por parte dos municípios considerados. Por outro lado, e de forma relativamente contra-intuitiva, uma maior população municipal, uma maior densidade populacional e 
um maior crescimento do PIB estariam relacionados com menores gastos municipais. Os resultados permitem concluir também a presença de ciclos eleitorais racionais - à la Rogoff (1990), e Rogoff e Sibert (1998) - nas variáveis selecionadas.

No caso da análise das entidades da Federação brasileira, um trabalho importante a ser considerado é o realizado por Cossio (1998), no qual é estimado um painel para variáveis fiscais dos Estados brasileiros para o período que compreende os anos de 1985 a 1997: de acordo com os resultados obtidos pelo autor, são encontradas evidências estatisticamente significantes no caso da dummy de ano eleitoral, sugerindo a existência de impulsos positivos de despesa em anos eleitorais; no caso do grau de participação do eleitorado, indicando que um maior grau de participação da sociedade no processo político (eleições) levaria à uma maior disciplina fiscal do governante e, no caso do grau de fragmentação partidária, sugerindo que uma maior dificuldade em formar maiorias de governo estaria relacionada de forma positiva com um maior volume de gastos - maior dificuldade em realizar ajuste fiscal. No caso das dummies de ideologia partidária (partido do governador estadual ser de esquerda, centro ou direita) e no caso da competitividade (número de candidatos por cadeira nas assembléias estaduais) não são encontradas evidências estatisticamente significantes, ao passo que no caso da dummy de coincidência do partido do governador e do partido do presidente da República, o resultado obtido é negativo e significativo, sugerindo um maior ajuste fiscal por parte dos partidos aliados do governo federal durante o período analisado.

É importante ressaltar a existência de trabalhos relevantes que analisam a influência de fatores econômicos sobre a probabilidade de reeleição do governante, ou seja, é estabelecida uma relação causal (fatores econômicos determinando um evento político) inversa à proposta no trabalho aqui realizado (fatores políticos determinando um evento econômico). Sobre tal questão, uma primeira referência relevante é o trabalho de Libanio (2003), em que é avaliada a probabilidade de reeleição dos governadores estaduais entre 1982 e 1998: os resultados obtidos permitem observar que o aumento da pobreza nos Estados brasileiros influencia negativamente a permanência no poder, embora nenhuma influência seja exercida pela desigualdade de renda. Adicionalmente, maiores chances de reeleição seriam observadas nos Estados com uma maior proporção de indivíduos trabalhando no setor agrícola, sugerindo que, nestes casos, haveria uma maior dificuldade em conhecer novos postulantes ao cargo (opositores ao incumbente), bem como nos Estados em que exista uma maior quantidade de ativos domésticos possuídos pelas famílias. De qualquer forma, os resultados sugerem uma percepção generalizada de que a melhora dos indicadores sociais seria sinalizadora da qualidade da administração pública e que, conseqüentemente, seria recompensada pelos eleitores com uma maior probabilidade de manter um candidato/partido no poder.

Ainda no que diz respeito à reeleição, um segundo trabalho relevante é o de Mendes e Rocha (2003), cujo objetivo é analisar a probabilidade de reeleição dos prefeitos brasileiros na eleição de 2000: os resultados indicam que municípios criados entre 1993 e 1996 apresentam maiores probabilidades de tentativa e de obtenção efetiva da reeleição, sinalizando que municípios mais novos praticamente não possuem endividamento e, portanto, possuem um orçamento com menos restrições à execução orçamentária. Adicionalmente, o alinhamento partidário com o presidente da República e o desempenho na eleição de 1996 também tendem a afetar positivamente as chances de um prefeito manter-se no poder. Por fim, há evidências de que denúncias de crimes graves parecem afetar (negativamente) somente os candidatos da região Sul e Sudeste do país, enquanto parecem não ter influência sobre o desempenho político dos candidatos do Norte e Nordeste, sendo assim uma alusão indireta às diferenças educacionais e institucionais entre tais regiões. 


\section{METODOLOGIA, MODELO SUGERIDO E HIPÓTESES}

O escopo desta análise envolve os municípios do Estado de São Paulo (572 municípios), ao longo de 13 anos (1989-2001). ${ }^{2}$ A hipótese levantada neste estudo é que o comportamento da despesa municipal e seus componentes, além de estarem relacionados ao volume de recursos disponíveis pela localidade (receitas, ou seja, fator econômico), estariam relacionados também a fatores de ordem política: à vigência do calendário eleitoral (anos de eleição municipal) e às diferenças de postura ideológica entre os partidos políticos. Os dados orçamentários e as características demográficas foram obtidos por intermédio da Fundação SEADE. ${ }^{3}$ Já as variáveis políticas foram obtidas por intermédio do TRE-SP (dados sobre candidatos/partidos eleitos nas eleições municipais de 1988, 1992, 1996 e 2000). Ressalta-se que as despesas aqui consideradas são aquelas efetivamente executadas pelas prefeituras paulistas, e não somente as orçadas pelas mesmas.

Para as estimações realizadas neste trabalho, foram selecionados cinco componentes da despesa orçamentária municipal que, a princípio, poderiam estar mais sujeitos a fatores de ordem política e, como procedimento tradicional em situações desta natureza, tais variáveis foram transformadas em valores per capita (as variáveis já estão em reais de 2002). ${ }^{4}$ Os componentes de despesa municipal selecionados foram: (i) despesa orçamentária (componente agregado da despesa); (ii) despesa corrente; (iii) despesa de pessoal; (iv) despesas com transferências correntes; (v) despesa de investimentos e, finalmente, (vi) receitas.

A escolha destas variáveis justifica-se pelo fato de que a variável despesa corrente seria uma medida de consumo do governo (cujo componente de maior peso financeiro são as despesas de pessoal), existindo, por outro lado, as despesas com investimento da administração pública municipal. A variável despesa com transferências correntes ${ }^{5}$ pode ser considerada importante, pois é um dos mecanismos mais rápidos de transmissão dos recursos públicos aos eleitores e, portanto, seria um instrumento relevante de ação para o governante. A variável receita foi selecionada por ser uma variável relevante na determinação do comportamento das despesas, uma vez que o volume de recursos empenhados está certamente condicionado ao volume de recursos disponíveis.

Tendo em mente as considerações anteriores, a forma funcional implementada tem como referência as formas propostas por Meneguin e Bugarin (2001), Cossio (1998) e Petterson-Lidbom (2001), para dados em painel, sendo cada componente de despesa regredido em função de dummies de ano ${ }^{6}$ e em função de dummies de partido, ${ }^{7}$ sendo criadas variáveis dicotômicas para cada um dos seis partidos mais freqüentes dentro da amostra - os demais foram incluídos numa categoria geral denominada "outros partidos".

As variáveis de controle consideradas são: (i) a receita municipal, a proporção de (ii) idosos (indivíduos com idade superior a 65 anos) e (iii) crianças e jovens (indivíduos com idade entre 0 e 15 anos) residindo em um município; (iv) grau de urbanização; (v) população total (em logaritmo natural) e, finalmente, (vi) uma dummy que assume o valor 1, caso o partido do prefeito e do governador do Estado sejam os mesmos (0 caso contrário).

2 Esta foi a maior dimensão temporal obtida para a análise dos dados

"Informações dos municípios paulistas"

Por meio da utilização do IGP-DI-FGV.

5 Dotações destinadas a terceiros sem a correspondente prestação/contrapartida de serviços ou bens, incluindo subvenções sociais, juros da dívida e contribuição de previdência social, entre outros.

6 Por exemplo, a dummy do ano de 1989 assume o valor 1 caso a observação seja associada a tal ano e 0 caso contrário, e assim para cada um dos anos considerados na amostra.

7 Por exemplo, a dummy associada ao PMDB assume 1 quando o prefeito é deste partido e 0 caso contrário, e assim para cada um dos partidos considerados.

8 A inclusão de tais variáveis demográficas segue alguns trabalhos já conhecidos na literatura como, por exemplo, Shi e SVENSSON (2002), e Persson e Tabellini (2002). 
Tendo em mente os conceitos estabelecidos pela teoria dos ciclos políticos, seria razoável esperar que, em anos eleitorais, procurando obter uma maior probabilidade de reeleição, o governante promoveria "impulsos" de despesa (na agregada ou somente em alguns de seus componentes) para promover uma maior oferta de recursos públicos e, em conseqüência, obter um maior grau de popularidade em relação aos eleitores: as dummies de ano proporcionariam a análise deste fato potencial. Por sua vez, no tocante aos partidos políticos, caso haja algum grau de consistência ideológica por parte dos mesmos, seria razoável esperar também que o comportamento dos componentes de despesa estaria sujeito a estas diferenças de postura partidária, fato este que seria captado pelas dummies de partido.

Ressalta-se que as receitas aqui consideradas excluem aquelas oriundas de tributos municipais (IPTU e ISS, entre outros), dado que, em anos eleitorais, pode existir um incentivo ao prefeito municipal para realizar um menor esforço arrecadatório (custo político). A existência desta possibilidade poderia gerar estimações viesadas, dada a endogeneidade existente entre receitas tributárias e as dummies de ano (E[receitas tributárias | ano eleitoral $] \neq \mathbf{0})$. A receita municipal oriunda de transferências (que representa boa parte dos recursos disponíveis aos municípios) estaria menos sujeita a este problema, pois o repasse por parte do governo estadual e federal é definido por lei.

A medida adotada com relação aos municípios que foram criados ao longo do período em análise foi a exclusão dos mesmos da amostra, ${ }^{9}$ pois, caso a criação destes esteja sujeita à fatores de ordem política (o que não é uma hipótese de toda descartável), então existe a possibilidade de alguma endogeneidade entre a criação destes municípios e as variáveis explicativas do modelo, o que poderia ocasionar problemas nas estimações realizadas. Os demais municípios pertencentes ao escopo desta análise (o Estado de São Paulo, inclusive a capital) estão incluídos nas estimações.

\section{RESUltados $^{10}$}

A partir desta parte do trabalho, são apresentados os resultados obtidos para cada uma das cinco variáveis orçamentárias aqui consideradas. Para todas as regressões, a forma funcional estimada é a mesma, sendo que os valores entre parênteses nas tabelas, com os resultados das estimações, representam o erro padrão para cada coeficiente. Ressalta-se que o PT (Partido dos Trabalhadores) foi retirado da estimação para evitar o problema de multicolinearidade perfeita, sendo, portanto, o partido de referência na análise do comportamento dos partidos políticos. O mesmo raciocínio é válido para justificar a ausência da dummy de 1989 nas estimações.

Considerando que $\mathbf{f}$ seja o efeito fixo de cada município, $\mathbf{X}$ o conjunto de regressores e $\mathbf{U}$ o resíduo da regressão, foram implementados três métodos de estimação existentes, dada a estrutura dos dados disponíveis: efeitos aleatórios [hipótese de $\mathbf{E}[\mathbf{F} \mid \mathbf{x}=\mathbf{0}]$ para ser não viesado], efeitos fixos (hipótese de $\mathbf{E}\left[\mathbf{U}_{\mathrm{it}} \mid \mathbf{X}_{\mathrm{is}}\right]=\mathbf{0}, \forall \mathbf{i}$, s para ser não viesado) e finalmente, Mínimos Quadrados Ordi-

9 Foram excluídos setenta e três municípios dos seiscentos e quarenta e cinco atualmente existentes.

10 Considere, para as estimações:

***: coeficiente estatisticamente significante a $1 \%$;

**: coeficiente estatisticamente significante a $5 \%$;

*: coeficiente estatisticamente significante a $10 \%$; 
nários. Todos os resultados reportados e analisados são os obtidos por meio do método de efeitos fixos, ${ }^{11}$ conforme sugerido pelo teste de Hausman. ${ }^{12,13}$

No sentido de verificar se, nos anos eleitorais, são observadas, de fato, alterações estatisticamente significantes nas despesas municipais (relativamente ao ano anterior e posterior), são apresentados os seguintes testes de hipótese: dummy 1991 = dummy 1992; dummy 1992 = dummy 1993; dummy 1995 = dummy 1996 e dummy $1996=$ dummy 1997. Também foram realizados os testes de hipótese de similaridade dos partidos políticos, para cada uma das variáveis orçamentárias analisadas, com base nos coeficientes das dummies de partido. No Apêndice deste trabalho são apresentadas as estatísticas obtidas para cada um dos testes acima (Tabela 3), bem como os gráficos das dummies de ano e de partido, conforme obtidas por meio das estimações (ressalta-se que tais ilustrações reportam os coeficientes das dummies efetivamente obtidas nas estimações, ou seja, tendo o ano de 1989 como referência para as dummies de ano e o PT como referência para as dummies de partido).

Destaca-se que, no sentido de testar a robustez dos resultados obtidos, duas formas alternativas para a receita são consideradas: a primeira delas consiste em controlar as estimações pela receita orçamentária (receita total) do município, enquanto a segunda consiste em considerar somente a receita de transferências governamentais. Os resultados obtidos a partir destes dois procedimentos são apresentados no Apêndice deste trabalho e demonstram que os resultados não sofrem alterações significativas, sendo observadas apenas alterações em termos de significância de alguns coeficientes, mas preservando em boa parte os sinais.

A título de ilustração, a Tabela 1 apresenta os resultados de um modelo em que se pressupõe a inexistência de influência das variáveis políticas sobre as variáveis dependentes, ou seja, apenas as variáveis de controle são consideradas - permanecem as dummies de tempo apenas como forma de controlar as estimações por eventuais efeitos específicos a cada ano, mas sem nenhuma apreciação específica a respeito dos anos eleitorais.

Observa-se a influência positiva e estatisticamente significante (a $1 \%$ nos cinco casos) da receita disponível sobre as cinco categorias de despesa analisadas, o que é um resultado esperado, pois, como justificado anteriormente, o montante de despesas certamente está condicionado ao montante de recursos disponíveis pela prefeitura municipal. Entretanto, ressalta-se que estes resultados não podem ser levados a uma análise mais profunda, dado que as receitas aqui consideradas excluem os tributos municipais, como já observado anteriormente. Quanto às variáveis demográficas (considerando como nível estatístico limite 10\%), uma maior proporção de idosos residindo nos municípios paulistas afeta negativamente tanto a despesa orçamentária como a despesa corrente, embora afete positivamente as transferências correntes. Em particular, este último resultado pode ser considerado esperado, uma vez que uma elevada proporção de indivíduos nesta faixa etária pode, muitas vezes, significar uma maior necessidade de atuação do setor público de forma direta, por meio da concessão de recursos públicos a pessoas (de direito público ou privado), para financiar suas despesas correntes.

11 Os resultados obtidos para os demais métodos estão disponíveis sob solicitação.

12 Teste de Hausman:

$\mathrm{H}_{0}=$ os estimadores do modelo de efeitos fixos e do modelo de efeitos aleatórios são ambos consistentes, mas o de efeitos aleatórios é eficiente;

$\mathrm{H}_{\mathrm{a}}=$ só os estimadores de efeitos fixos são consistentes.

O teste é distribuído por meio de uma $\chi^{2} \operatorname{com} n$ (número de coeficientes estimados) graus de liberdade.

13 Em todas as estimações, o teste de Hausman não aceita a hipótese nula, ou seja, o método consistente vem a ser o método de efeitos fixos. 
Tabela 1 - Resultados das regressões - modelo sem variáveis políticas - método de efeitos fixos

\begin{tabular}{|c|c|c|c|c|c|}
\hline & $\begin{array}{c}\text { Despesa } \\
\text { orçamentária }\end{array}$ & $\begin{array}{l}\text { Despesa } \\
\text { corrente }\end{array}$ & $\begin{array}{c}\text { Despesa de } \\
\text { pessoal }\end{array}$ & $\begin{array}{c}\text { Transferências } \\
\text { correntes }\end{array}$ & Investimentos \\
\hline Receita & $\begin{array}{l}0.927^{* * *} \\
(0.007)\end{array}$ & $\begin{array}{l}0.508^{\star \star *} \\
(0.006)\end{array}$ & $\begin{array}{l}0.221^{* * *} \\
(0.004)\end{array}$ & $\begin{array}{l}0.068^{* * *} \\
(0.003)\end{array}$ & $\begin{array}{l}0.395^{\star * *} \\
(0.006)\end{array}$ \\
\hline Dummy 1990 & $\begin{array}{l}84.879^{* \star *} \\
(5.963)\end{array}$ & $\begin{array}{l}55.837^{\star \star \star} \\
(4.863)\end{array}$ & $\begin{array}{l}21.657^{\star * *} \\
(3.278)\end{array}$ & $\begin{array}{l}-0.594 \\
(2.139)\end{array}$ & $\begin{array}{l}27.465^{\star \star \star} \\
(5.281)\end{array}$ \\
\hline Dummy 1991 & $\begin{array}{l}92.580^{\star * *} \\
(6.440)\end{array}$ & $\begin{array}{l}74.136^{* \star *} \\
(5.251)\end{array}$ & $\begin{array}{l}28.496^{* * *} \\
(3.540)\end{array}$ & $\begin{array}{c}3.605 \\
(2.309)\end{array}$ & $\begin{array}{l}19.311^{* * *} \\
(5.703)\end{array}$ \\
\hline Dummy 1992 & $\begin{array}{c}127.839^{* * *} \\
(7.200)\end{array}$ & $\begin{array}{c}109.716^{* * *} \\
(5.875)\end{array}$ & $\begin{array}{l}38.402^{* * *} \\
(3.968)\end{array}$ & $\begin{array}{l}7.273^{* * *} \\
(2.583)\end{array}$ & $\begin{array}{l}20.751^{* * *} \\
(6.384)\end{array}$ \\
\hline Dummy 1993 & $\begin{array}{l}26.274^{\star * *} \\
(8.060)\end{array}$ & $\begin{array}{l}61.526^{* \star \star} \\
(6.573)\end{array}$ & $\begin{array}{l}29.506^{* \star \star} \\
(4.440)\end{array}$ & $\begin{array}{l}8.337^{\star \star *} \\
(2.890)\end{array}$ & $\begin{array}{c}-34.253^{\star * *} \\
(7.139)\end{array}$ \\
\hline Dummy 1994 & $\begin{array}{c}90.264^{* * *} \\
(9.114)\end{array}$ & $\begin{array}{l}83.384^{* \star \star} \\
(7.433)\end{array}$ & $\begin{array}{l}19.952^{* * \star} \\
(5.011)\end{array}$ & $\begin{array}{l}9.177^{\star \star *} \\
(3.268)\end{array}$ & $\begin{array}{c}6.695 \\
(8.074)\end{array}$ \\
\hline Dummy 1995 & $\begin{array}{l}153.933^{* * *} \\
(10.129)\end{array}$ & $\begin{array}{c}173.656^{\star \star *} \\
(8.260)\end{array}$ & $\begin{array}{l}69.668^{* * *} \\
(5.569)\end{array}$ & $\begin{array}{l}20.243^{* * *} \\
(3.631)\end{array}$ & $\begin{array}{c}-21.584^{* *} \\
(8.973)\end{array}$ \\
\hline Dummy 1996 & $\begin{array}{l}168.255^{* * *} \\
(11.258)\end{array}$ & $\begin{array}{c}216.638^{* * *} \\
(9.181)\end{array}$ & $\begin{array}{c}102.352^{* * \star} \\
(6.191)\end{array}$ & $\begin{array}{l}25.749^{* * *} \\
(4.037)\end{array}$ & $\begin{array}{c}-51.009^{* * *} \\
(9.974)\end{array}$ \\
\hline Dummy 1997 & $\begin{array}{l}98.423^{\star * *} \\
(12.205)\end{array}$ & $\begin{array}{c}196.488^{\star \star \star} \\
(9.953)\end{array}$ & $\begin{array}{c}122.588^{* \star \star} \\
(6.712)\end{array}$ & $\begin{array}{l}27.626^{* \star \star} \\
(4.376)\end{array}$ & $\begin{array}{l}-99.431^{* \star *} \\
(10.812)\end{array}$ \\
\hline Dummy 1998 & $\begin{array}{l}107.101^{* * *} \\
(13.208)\end{array}$ & $\begin{array}{l}211.004^{* * *} \\
(10.770)\end{array}$ & $\begin{array}{c}109.428^{* * *} \\
(7.266)\end{array}$ & $\begin{array}{l}89.239^{* * *} \\
(4.735)\end{array}$ & $\begin{array}{c}-104.380^{* * *} \\
(11.702)\end{array}$ \\
\hline Dummy 1999 & $\begin{array}{l}80.475^{\star * \star} \\
(14.176)\end{array}$ & $\begin{array}{c}218.789^{\star * *} \\
(11.560)\end{array}$ & $\begin{array}{c}104.708^{* * \star} \\
(7.795)\end{array}$ & $\begin{array}{l}93.328^{* * *} \\
(5.082)\end{array}$ & $\begin{array}{c}-139.967^{\star * *} \\
(12.558)\end{array}$ \\
\hline Dummy 2000 & $\begin{array}{l}67.173^{\star * *} \\
(15.194)\end{array}$ & $\begin{array}{l}212.812^{\star \star \star} \\
(12.390)\end{array}$ & $\begin{array}{c}120.971^{* * \star} \\
(8.355)\end{array}$ & $\begin{array}{l}77.154^{* \star *} \\
(5.446)\end{array}$ & $\begin{array}{c}-142.129^{\star \star \star} \\
(13.461)\end{array}$ \\
\hline Dummy 2001 & $\begin{array}{l}50.407^{\star * \star} \\
(16.274)\end{array}$ & $\begin{array}{l}216.595^{\star * \star} \\
(13.271)\end{array}$ & $\begin{array}{c}118.456^{* \star *} \\
(8.949)\end{array}$ & $\begin{array}{l}83.981^{* * *} \\
(5.835)\end{array}$ & $\begin{array}{c}-163.453^{\star \star \star} \\
(14.421)\end{array}$ \\
\hline Idosos & $\begin{array}{l}-5.603^{*} \\
(3.090)\end{array}$ & $\begin{array}{l}-4.507^{*} \\
(2.520)\end{array}$ & $\begin{array}{c}1.911 \\
(1.699)\end{array}$ & $\begin{array}{l}3.667^{\star \star *} \\
(1.109)\end{array}$ & $\begin{array}{l}-0.402 \\
(2.743)\end{array}$ \\
\hline Urbanização & $\begin{array}{l}-0.364 \\
(0.391)\end{array}$ & $\begin{array}{c}0.136 \\
(0.319)\end{array}$ & $\begin{array}{l}0.687^{* * *} \\
(0.215)\end{array}$ & $\begin{array}{l}0.965^{\star \star *} \\
(0.140)\end{array}$ & $\begin{array}{l}-0.575^{*} \\
(0.347)\end{array}$ \\
\hline Jovens & $\begin{array}{c}0.651 \\
(1.974)\end{array}$ & $\begin{array}{l}6.035^{\star \star \star} \\
(1.610)\end{array}$ & $\begin{array}{l}3.842^{\star \star \star} \\
(1.086)\end{array}$ & $\begin{array}{l}2.446^{\star \star *} \\
(0.707)\end{array}$ & $\begin{array}{l}-4.104^{* *} \\
(1.749)\end{array}$ \\
\hline População & $\begin{array}{l}74.230^{* * *} \\
(15.731)\end{array}$ & $\begin{array}{c}15.967 \\
(12.828)\end{array}$ & $\begin{array}{r}-11.820 \\
(8.651)\end{array}$ & $\begin{array}{c}-38.213^{* * *} \\
(5.660)\end{array}$ & $\begin{array}{l}73.300^{* * *} \\
(13.941)\end{array}$ \\
\hline Constante & $\begin{array}{l}-628.046^{* * *} \\
(165.531)\end{array}$ & $\begin{array}{l}-189.740 \\
(134.985)\end{array}$ & $\begin{array}{c}-0.696 \\
(91.031)\end{array}$ & $\begin{array}{l}183.884^{* * *} \\
(59.505)\end{array}$ & $\begin{array}{l}-617.088^{\star * \star} \\
(146.731)\end{array}$ \\
\hline $\mathrm{R}^{2}$ & 0.8769 & 0.8072 & 0.7064 & 0.1818 & 0.4746 \\
\hline Observações & 7267 & 7265 & 7244 & 7256 & 7256 \\
\hline Teste de Hausman & $\begin{array}{l}x^{2}=739.08 \\
\text { Prob }=0,00\end{array}$ & $\begin{array}{l}x^{2}=1030,85 \\
\text { Prob }=0,00\end{array}$ & $\begin{array}{l}x^{2}=400.93 \\
\text { Prob }=0,00\end{array}$ & $\begin{array}{l}x^{2}=178.46 \\
\text { Prob }=0,00\end{array}$ & $\begin{array}{l}x^{2}=127.06 \\
\text { Prob }=0,00\end{array}$ \\
\hline
\end{tabular}


Quanto à urbanização, observa-se uma relação positiva com o montante financeiro executado na despesa de pessoal e nas transferências correntes e uma relação negativa com os investimentos. Tais resultados podem ser explicados pelo fato de que municípios mais urbanizados possuem maior capacidade (ou necessidade) de provisão de serviços públicos, com a conseqüente necessidade de um quadro de funcionários mais significativo. Por sua vez, pode ser válida também a percepção de que municípios mais urbanizados possuem condições de infra-estrutura mais concretas, minimizando a demanda por investimentos comparativamente a municípios em que o grau de urbanização ainda seja reduzido.

Para o caso da proporção de crianças e jovens, observa-se uma relação positiva com as despesas correntes, despesa de pessoal e transferências correntes e uma relação negativa no caso dos investimentos. Uma possível justificativa para este caso seria próxima ao exposto anteriormente, ou seja, em municípios com uma maior proporção de indivíduos nesta faixa etária, maiores seriam as demandas por saúde e educação básica, por exemplo; necessitando, conseqüentemente, uma maior alocação de recursos para a manutenção de tais setores.

Finalmente, os municípios mais populosos tendem a executar mais recursos no agregado do orçamento municipal e nos investimentos, sugerindo, portanto, que municípios de maior porte populacional eventualmente possuam uma maior necessidade ou mesmo possibilidade de intervenção estatal por meio de maiores investimentos públicos, entre outros fatores. Adicionalmente, quanto mais populosos os municípios, menos recursos são executados nas transferências correntes.

Partindo para a análise do modelo geral, em que todos os regressores são inseridos nas estimações, os resultados da Tabela 2 demonstram que, em todas as regressões, a receita apresenta relação positiva com o volume de recursos despendidos, com coeficientes estatisticamente significantes (a no máximo $10 \%$ ), como observado na Tabela 1 - ressalta-se inclusive a pequena variação no valor dos coeficientes entre as duas análises.

No que diz respeito às dummies de similaridade entre partido do prefeito municipal e partido do governador estadual, nenhum dos coeficientes apresenta significância estatística, ao contrário do resultado obtido por Cossio (1998), no qual, como já visto anteriormente, é obtido um coeficiente estatisticamente significativo e negativo no caso do alinhamento partidário entre governadores estaduais e presidente da República. Uma possível justificativa para este contraste pode residir na própria diferença das amostras (Estados brasileiros entre 1985 e 1997 e municípios paulistas entre 1989 e 2001), bem como na própria diferença entre os partidos que estiveram na presidência da República e os partidos que estiveram no governo paulista. Destaca-se inclusive que, entre 1989 e 2001, o Estado de São Paulo esteve sob comando de apenas dois partidos: PMDB e PSDB. Assim, os resultados apresentados na Tabela 2 sugerem que, em relação a estes dois partidos, não há indícios de que o alinhamento partidário com as prefeituras represente alguma diferença no comportamento das cinco variáveis aqui abordadas. Já para o caso das variáveis demográficas, os resultados são praticamente os mesmos dos apresentados na Tabela 1, uma vez que seus sinais e suas significâncias estatísticas permanecem os mesmos, ocorrendo apenas alterações marginais nos valores assumidos. 
Tabela 2 - Resultados das regressões - modelo com variáveis políticas - método de efeitos fixos

\begin{tabular}{|c|c|c|c|c|c|}
\hline & $\begin{array}{c}\text { Despesa } \\
\text { orçamentária }\end{array}$ & $\begin{array}{l}\text { Despesa } \\
\text { corrente }\end{array}$ & $\begin{array}{c}\text { Despesa de } \\
\text { pessoal }\end{array}$ & $\begin{array}{l}\text { Transferências } \\
\text { correntes }\end{array}$ & Investimentos \\
\hline Receita & $\begin{array}{l}0.925^{* * *} \\
(0.007)\end{array}$ & $\begin{array}{l}0.508^{\star * *} \\
(0.006)\end{array}$ & $\begin{array}{l}0.221^{* * *} \\
(0.004)\end{array}$ & $\begin{array}{l}0.068^{\star \star \star} \\
(0.003)\end{array}$ & $\begin{array}{l}0.393^{* * *} \\
(0.006)\end{array}$ \\
\hline Dummy 1990 & $\begin{array}{l}84.908^{* * *} \\
(5.959)\end{array}$ & $\begin{array}{l}55.781^{* * *} \\
(4.863)\end{array}$ & $\begin{array}{l}21.633^{* * *} \\
(3.276)\end{array}$ & $\begin{array}{l}-0.611 \\
(2.138)\end{array}$ & $\begin{array}{l}27.558^{* * *} \\
(5.279)\end{array}$ \\
\hline Dummy 1991 & $\begin{array}{l}92.497^{* * *} \\
(6.436)\end{array}$ & $\begin{array}{l}74.047^{* * *} \\
(5.253)\end{array}$ & $\begin{array}{l}28.482^{* * *} \\
(3.539)\end{array}$ & $\begin{array}{c}3.594 \\
(2.309)\end{array}$ & $\begin{array}{l}19.355^{\star * *} \\
(5.702)\end{array}$ \\
\hline Dummy 1992 & $\begin{array}{c}127.637^{* * *} \\
(7.198)\end{array}$ & $\begin{array}{c}109.596^{* * *} \\
(5.878)\end{array}$ & $\begin{array}{l}38.410^{* * *} \\
(3.968)\end{array}$ & $\begin{array}{l}7.274^{* * *} \\
(2.584)\end{array}$ & $\begin{array}{l}20.723^{* * *} \\
(6.385)\end{array}$ \\
\hline Dummy 1993 & $\begin{array}{l}28.038^{* * *} \\
(8.096)\end{array}$ & $\begin{array}{l}62.307^{* * *} \\
(6.607)\end{array}$ & $\begin{array}{l}29.607^{* * *} \\
(4.461)\end{array}$ & $\begin{array}{l}8.524^{* * *} \\
(2.904)\end{array}$ & $\begin{array}{c}-33.626^{* * *} \\
(7.173)\end{array}$ \\
\hline Dummy 1994 & $\begin{array}{l}91.981^{* * *} \\
(9.145)\end{array}$ & $\begin{array}{l}84.112^{* * *} \\
(7.463)\end{array}$ & $\begin{array}{l}20.010^{* * *} \\
(5.029)\end{array}$ & $\begin{array}{l}9.353^{* * *} \\
(3.280)\end{array}$ & $\begin{array}{c}7.337 \\
(8.103)\end{array}$ \\
\hline Dummy 1995 & $\begin{array}{l}157.884^{* * *} \\
(10.334)\end{array}$ & $\begin{array}{c}174.445^{* * *} \\
(8.434)\end{array}$ & $\begin{array}{l}69.863^{* * *} \\
(5.684)\end{array}$ & $\begin{array}{l}20.170^{* * *} \\
(3.707)\end{array}$ & $\begin{array}{c}-18.916^{* *} \\
(9.157)\end{array}$ \\
\hline Dummy 1996 & $\begin{array}{l}172.240^{* * *} \\
(11.443)\end{array}$ & $\begin{array}{c}217.392^{* * *} \\
(9.339)\end{array}$ & $\begin{array}{c}102.535^{* * *} \\
(6.294)\end{array}$ & $\begin{array}{l}25.663^{* * *} \\
(4.105)\end{array}$ & $\begin{array}{l}-48.269^{\star \star *} \\
(10.141)\end{array}$ \\
\hline Dummy 1997 & $\begin{array}{l}98.539^{\star * *} \\
(12.376)\end{array}$ & $\begin{array}{l}196.369^{* * *} \\
(10.101)\end{array}$ & $\begin{array}{c}121.631^{* * *} \\
(6.808)\end{array}$ & $\begin{array}{l}28.233^{* * *} \\
(4.439)\end{array}$ & $\begin{array}{l}-99.027^{* * *} \\
(10.967)\end{array}$ \\
\hline Dummy 1998 & $\begin{array}{l}107.179^{* * *} \\
(13.372)\end{array}$ & $\begin{array}{l}210.774^{* * *} \\
(10.913)\end{array}$ & $\begin{array}{c}108.429^{\star * *} \\
(7.359)\end{array}$ & $\begin{array}{l}89.796^{* * *} \\
(4.796)\end{array}$ & $\begin{array}{c}-103.880^{* * *} \\
(11.851)\end{array}$ \\
\hline Dummy 1999 & $\begin{array}{l}80.355^{* * *} \\
(14.336)\end{array}$ & $\begin{array}{l}218.519^{* * *} \\
(11.700)\end{array}$ & $\begin{array}{c}103.741^{* * *} \\
(7.885)\end{array}$ & $\begin{array}{l}93.891^{* * *} \\
(5.142)\end{array}$ & $\begin{array}{c}-139.584^{* * *} \\
(12.704)\end{array}$ \\
\hline Dummy 2000 & $\begin{array}{l}66.993^{* * *} \\
(15.347)\end{array}$ & $\begin{array}{l}212.464^{* * *} \\
(12.525)\end{array}$ & $\begin{array}{c}119.981^{* * *} \\
(8.442)\end{array}$ & $\begin{array}{l}77.694^{* * *} \\
(5.503)\end{array}$ & $\begin{array}{c}-141.698^{* * *} \\
(13.602)\end{array}$ \\
\hline Dummy 2001 & $\begin{array}{l}50.483^{* * *} \\
(16.390)\end{array}$ & $\begin{array}{l}216.171^{* * *} \\
(13.376)\end{array}$ & $\begin{array}{c}117.342^{* * *} \\
(9.015)\end{array}$ & $\begin{array}{l}84.670^{* * *} \\
(5.880)\end{array}$ & $\begin{array}{c}-162.720^{* * *} \\
(14.528)\end{array}$ \\
\hline PFL & $\begin{array}{l}20.824^{* *} \\
(10.269)\end{array}$ & $\begin{array}{c}0.339 \\
(8.381)\end{array}$ & $\begin{array}{l}-6.472 \\
(5.647)\end{array}$ & $\begin{array}{l}6.030 \\
(3.678)\end{array}$ & $\begin{array}{l}17.237^{*} \\
(9.098)\end{array}$ \\
\hline PPB / PDS & $\begin{array}{c}15.071 \\
(10.835)\end{array}$ & $\begin{array}{c}6.943 \\
(8.843)\end{array}$ & $\begin{array}{c}2.522 \\
(5.960)\end{array}$ & $\begin{array}{l}9.365^{* *} \\
(3.881)\end{array}$ & $\begin{array}{l}5.804 \\
(9.600)\end{array}$ \\
\hline PMDB & $\begin{array}{c}7.058 \\
(10.417)\end{array}$ & $\begin{array}{l}-0.956 \\
(8.502)\end{array}$ & $\begin{array}{l}-4.948 \\
(5.728)\end{array}$ & $\begin{array}{l}8.052^{* *} \\
(3.731)\end{array}$ & $\begin{array}{l}6.530 \\
(9.231)\end{array}$ \\
\hline PSDB & $\begin{array}{l}14.298 \\
(11.266)\end{array}$ & $\begin{array}{c}1.422 \\
(9.195)\end{array}$ & $\begin{array}{l}-0.853 \\
(6.198)\end{array}$ & $\begin{array}{c}6.098 \\
(4.035)\end{array}$ & $\begin{array}{c}9.661 \\
(9.984)\end{array}$ \\
\hline PTB & $\begin{array}{l}28.564^{* * *} \\
(10.639)\end{array}$ & $\begin{array}{c}8.309 \\
(8.683)\end{array}$ & $\begin{array}{c}2.025 \\
(5.851)\end{array}$ & $\begin{array}{l}9.446^{* *} \\
(3.811)\end{array}$ & $\begin{array}{l}14.250 \\
(9.426)\end{array}$ \\
\hline OUTROS & $\begin{array}{r}19.029^{\star} \\
(10.305)\end{array}$ & $\begin{array}{l}-1.723 \\
(8.410)\end{array}$ & $\begin{array}{l}-2.901 \\
(5.667)\end{array}$ & $\begin{array}{c}5.595 \\
(3.692)\end{array}$ & $\begin{array}{l}18.455^{* *} \\
(9.130)\end{array}$ \\
\hline $\begin{array}{l}\text { Prefeito e } \\
\text { Governador }\end{array}$ & $\begin{array}{c}5.808 \\
(4.777)\end{array}$ & $\begin{array}{c}0.310 \\
(3.899)\end{array}$ & $\begin{array}{c}0.446 \\
(2.632)\end{array}$ & $\begin{array}{l}-0.596 \\
(1.712)\end{array}$ & $\begin{array}{l}5.100 \\
(4.235)\end{array}$ \\
\hline Idosos & $\begin{array}{l}-6.105^{* *} \\
(3.094)\end{array}$ & $\begin{array}{l}-4.702^{*} \\
(2.525)\end{array}$ & $\begin{array}{c}1.890 \\
(1.702)\end{array}$ & $\begin{array}{l}3.638^{* * *} \\
(1.111)\end{array}$ & $\begin{array}{l}-0.617 \\
(2.748)\end{array}$ \\
\hline Urbanização & $\begin{array}{l}-0.342 \\
(0.392)\end{array}$ & $\begin{array}{c}0.162 \\
(0.320)\end{array}$ & $\begin{array}{l}0.698^{* * *} \\
(0.216)\end{array}$ & $\begin{array}{l}0.981^{* * *} \\
(0.141)\end{array}$ & $\begin{array}{l}-0.582^{*} \\
(0.347)\end{array}$ \\
\hline Jovens & $\begin{array}{c}0.498 \\
(1.979)\end{array}$ & $\begin{array}{l}5.959^{\star * *} \\
(1.615)\end{array}$ & $\begin{array}{l}3.851^{* * *} \\
(1.088)\end{array}$ & $\begin{array}{l}2.454^{* \star *} \\
(0.709)\end{array}$ & $\begin{array}{l}-4.135^{* *} \\
(1.754)\end{array}$ \\
\hline População & $\begin{array}{l}74.045^{\star * *} \\
(15.740)\end{array}$ & $\begin{array}{c}15.816 \\
(12.846)\end{array}$ & $\begin{array}{r}-11.228 \\
(8.658)\end{array}$ & $\begin{array}{c}-37.973^{* * *} \\
(5.666)\end{array}$ & $\begin{array}{l}73.257^{\star * *} \\
(13.953)\end{array}$ \\
\hline Constante & $\begin{array}{l}-637.310^{* * *} \\
(166.198)\end{array}$ & $\begin{array}{l}-188.262 \\
(135.639)\end{array}$ & $\begin{array}{c}-4.533 \\
(91.422)\end{array}$ & $\begin{array}{l}173.036^{* * *} \\
(59.776)\end{array}$ & $\begin{array}{l}-626.709^{* * *} \\
(147.382)\end{array}$ \\
\hline$R^{2}$ & 0.8768 & 0.8074 & 0.7087 & 0.1831 & 0.4756 \\
\hline Observações & 7267 & 7265 & 7244 & 7256 & 7256 \\
\hline Teste de Hausman & $\begin{array}{r}X^{2}=818,61 \\
\text { Prob }=0,00\end{array}$ & $\begin{array}{l}x^{2}=1022,25 \\
\text { Prob }=0,00\end{array}$ & $\begin{array}{r}x^{2}=376,80 \\
\text { Prob }=0,00\end{array}$ & $\begin{array}{r}x^{2}=204,43 \\
\text { Prob }=0,00\end{array}$ & $\begin{array}{r}x^{2}=156,31 \\
\text { Prob }=0,00\end{array}$ \\
\hline
\end{tabular}


Partindo para a análise das variáveis políticas, apresenta-se uma análise específica para cada caso, considerando inclusive os resultados dos testes de hipótese apresentados na Tabela 4 do Apêndice, conforme segue.

\section{Despesa orçamentária}

No caso das despesas orçamentárias, os resultados obtidos pelos testes apresentam evidências estatisticamente significantes (a 5\%) de impulsos positivos ocorridos nos anos eleitorais de 1992 e 1996, tendo como referência os anos imediatamente anteriores (1991 e 1995) e os imediatamente posteriores (1993 e 1997), sugerindo assim um maior volume de recursos despendidos pelas prefeituras paulistas em tais anos. Já no que diz respeito às posturas partidárias, os resultados apresentam evidências estatisticamente significantes (a 5\%) para os partidos PFL, PTB (este notadamente) e para o conjunto "outros partidos”, cujos gastos são, em média, superiores aos gastos efetuados pelos demais partidos considerados, inclusive em relação ao partido de referência PT.

\section{Despesa corrente}

Resultado semelhante ao obtido no caso das despesas orçamentárias também é observado no caso das despesas correntes, uma vez que os impulsos positivos de gastos nos anos eleitorais de $1992 \mathrm{e}$ 1996 são novamente observados. Assim sendo, os impulsos positivos observados no agregado das despesas municipais podem ter como origem alterações promovidas na categoria das despesas correntes. Em termos do horizonte temporal analisado, observa-se também uma tendência positiva das dummies de ano, sugerindo assim um maior volume de recursos empenhados nesta categoria de despesa ao longo do período analisado, mesmo controlando por todas as variáveis consideradas. Já no que diz respeito aos partidos políticos, os resultados demonstram que $\mathrm{PTB}^{14}$ e $\mathrm{PPB} / \mathrm{PDS}^{15}$ são partidos que se destacam por alocarem relativamente mais recursos nesta categoria de despesa municipal.

\section{Despesa de pessoal}

No tocante às despesas de pessoal, o impulso positivo em ano eleitoral é observado somente para 1992. No caso do ano de 1996, embora o impulso seja maior que em 1995, é menor que o valor observado em 1997, não configurando assim um típico comportamento eleitoral como observado no pleito anterior. Assim sendo, os resultados sugerem que, a princípio, esta é uma variável pouco suscetível à influência do calendário eleitoral.

Em relação ao comportamento dos partidos políticos, as evidências sugerem que aos partidos PPB/PDS e PTB estão associados maiores volumes de recursos despendidos nesta categoria de despesa do orçamento municipal, principalmente em relação ao PFL e ao PMDB.

\section{Transferências correntes}

Os resultados referentes às transferências correntes compõem um caso emblemático na análise dos ciclos eleitorais, uma vez que não são observadas evidências contundentes de impulsos de gastos nos anos eleitorais: os testes realizados não permitem rejeitar a hipótese de que a dummy de 1992 seja igual à dummy de 1993, ao passo que a dummy de 1996, embora estatisticamente diferente

14 Em relação ao PFL, PMDB e ao grupo "outros partidos".

15 Em relação ao grupo "outros partidos". 
da dummy de 1995 (a 1\%), pode ser considerada estatisticamente igual à dummy de 1997. Assim sendo, não são observadas evidências de impulsos oportunistas nesta variável, nos moldes aqui considerados. No que tange à postura dos partidos políticos, o caso das transferências correntes sugere que PDS/PPB, PTB e PMDB são os partidos políticos que mais alocam recursos nesta categoria do orçamento público, notadamente em relação ao PT. ${ }^{16}$

\section{Despesa de investimento}

Os resultados referentes às dummies de ano para o caso das despesas de investimento não apresentam evidências contundentes de ciclos eleitorais nos moldes aqui considerados: embora a dummy de 1992 seja estatisticamente diferente da dummy de 1993 (a 1\%), é estatisticamente igual à dummy de 1991. Para o ano de 1996, o resultado pode ser considerado distinto dos demais, dado o impulso negativo estatisticamente diferente dos anos de 1995 e 1997. Logo, como no caso das transferências correntes, não são observadas evidências de distorções oportunistas nos investimentos dos municípios paulistas. Em termos gerais, é interessante notar a dinâmica das dummies de ano, uma vez que se observa uma trajetória declinante das mesmas ao longo do período analisado (controlando pela receita).

No que diz respeito aos partidos políticos, os resultados apresentam evidências de que PFL e o grupo "outros partidos" apresentam as diferenças mais contundentes, empenhando um volume maior de recursos financeiros em investimentos públicos, notadamente em relação ao PT, PPB/ PDS e PMDB.

Neste ponto do trabalho, uma questão relevante diz respeito à interpretação do coeficiente associado à dummy do ano de 2000. Este é um ano relevante no cenário político brasileiro não só por ser um ano de eleições municipais (inclusive é o primeiro ano em que a possibilidade de reeleição dos prefeitos é permitida após a Constituição de 1988), mas principalmente por ser o ano em que entra em vigor a Lei de Responsabilidade Fiscal (LRF), fato que tem alterado de forma significativa o comportamento fiscal dos entes da Federação já no próprio ano de sua aprovação. ${ }^{17}$ Pelo fato de a dummy não conseguir captar de forma separada estes dois efeitos, os resultados referentes a este coeficiente foram apresentados na Tabela 2, embora nenhuma análise mais profunda sobre o mesmo é realizada, procurando evitar assim a obtenção de conclusões ou percepções equivocadas a seu respeito.

A título de ilustração, a Tabela 3 apresenta os resultados da estimação de uma forma funcional idêntica à apresentada na Tabela 2, mas com a retirada das dummies de ano e a inclusão de uma dummy que assume o valor 1 em 2000 e 2001, anos em que LRF já tende a apresentar alguma influência sobre a gestão fiscal (0 caso contrário). Conforme exposto, é possível observar que, nestes dois anos, há de fato uma significativa contração fiscal da despesa orçamentária (coeficiente igual à -60.55, estatisticamente significante a 1\%) em relação à média do período, originada não só a partir de uma redução nos gastos correntes como também a partir de uma queda nos investimentos. A despesa de pessoal aparentemente não sofre influência da LRF (uma vez que seu coeficiente é estatisticamente igual a zero), algo razoavelmente esperado dada a dificuldade em realizar contenções fiscais nesta categoria da despesa pública - resultado semelhante é obtido por Menezes (2005). Por sua vez, observa-se também que a LRF parece não influenciar o comportamento das transferências correntes.

16 Para os dois primeiros, há maiores transferências também em relação ao grupo “outros partidos”, conforme os testes de hipótese.

17 Conforme Nunes e Nunes (2003), a LRF entrou em vigor em maio de 2000. Ainda que se considere que, no primeiro ano, o ajuste fiscal foi parcial porque as administrações já trabalhavam com orçamentos aprovados no ano anterior, muitos ajustes que não dependiam dos orçamentos foram efetivamente realizados. Logo, são observadas ações de conservadorismo fiscal já no próprio ano de aprovação da lei.

18 Ressalta-se que tais resultados são relativamente robustos quando comparados às formas funcionais em que a receita total e a receita de transferências correntes são utilizadas como controle das regressões, conforme as Tabelas 7 e 10 do Apêndice deste trabalho. 
Tabela 3 - Resultados das regressões - teste da LRF - método de efeitos fixos

\begin{tabular}{|c|c|c|c|c|c|}
\hline & $\begin{array}{c}\text { Despesa } \\
\text { orçamentária }\end{array}$ & $\begin{array}{l}\text { Despesa } \\
\text { corrente }\end{array}$ & $\begin{array}{c}\text { Despesa de } \\
\text { pessoal }\end{array}$ & $\begin{array}{l}\text { Transferências } \\
\text { correntes }\end{array}$ & Investimentos \\
\hline Receita & $\begin{array}{l}0.929^{* * *} \\
(0.008)\end{array}$ & $\begin{array}{l}0.526^{* * *} \\
(0.006)\end{array}$ & $\begin{array}{l}0.233^{* * *} \\
(0.004)\end{array}$ & $\begin{array}{l}0.084^{* * *} \\
(0.003)\end{array}$ & $\begin{array}{l}0.379^{* * *} \\
(0.006)\end{array}$ \\
\hline Dummy LRF & $\begin{array}{c}-60.553^{* * *} \\
(4.592)\end{array}$ & $\begin{array}{c}-28.338^{* * *} \\
(3.728)\end{array}$ & $\begin{array}{l}-3.314 \\
(2.484)\end{array}$ & $\begin{array}{c}1.442 \\
(1.710)\end{array}$ & $\begin{array}{c}-27.289^{* * *} \\
(3.964)\end{array}$ \\
\hline PFL & $\begin{array}{l}22.041^{* *} \\
(11.042)\end{array}$ & $\begin{array}{c}2.100 \\
(8.966)\end{array}$ & $\begin{array}{l}-5.426 \\
(5.971)\end{array}$ & $\begin{array}{l}8.200^{\star *} \\
(4.109)\end{array}$ & $\begin{array}{r}16.899^{*} \\
(9.511)\end{array}$ \\
\hline PPB / PDS & $\begin{array}{c}18.353 \\
(11.647)\end{array}$ & $\begin{array}{c}8.396 \\
(9.457)\end{array}$ & $\begin{array}{c}2.622 \\
(6.300)\end{array}$ & $\begin{array}{c}9.095^{\star *} \\
(4.334)\end{array}$ & $\begin{array}{c}7.614 \\
(10.033)\end{array}$ \\
\hline PMDB & $\begin{array}{l}32.631^{* * *} \\
(11.104)\end{array}$ & $\begin{array}{l}14.398 \\
(9.017)\end{array}$ & $\begin{array}{l}-0.934 \\
(6.005)\end{array}$ & $\begin{array}{c}1.260 \\
(4.132)\end{array}$ & $\begin{array}{c}15.877^{*} \\
(9.565)\end{array}$ \\
\hline PSDB & $\begin{array}{l}31.704^{* * *} \\
(11.943)\end{array}$ & $\begin{array}{l}34.298^{* * *} \\
(9.697)\end{array}$ & $\begin{array}{l}20.339^{* * *} \\
(6.461)\end{array}$ & $\begin{array}{l}11.461^{\text {** }} \\
(4.445)\end{array}$ & $\begin{array}{c}-6.898 \\
(10.289)\end{array}$ \\
\hline PTB & $\begin{array}{l}31.056^{* * *} \\
(11.450)\end{array}$ & $\begin{array}{c}8.912 \\
(9.296)\end{array}$ & $\begin{array}{c}1.981 \\
(6.193)\end{array}$ & $\begin{array}{l}11.086^{\star * \star} \\
(4.261)\end{array}$ & $\begin{array}{c}16.477^{*} \\
(9.862)\end{array}$ \\
\hline OUTROS & $\begin{array}{r}20.918^{*} \\
(11.081)\end{array}$ & $\begin{array}{l}-3.236 \\
(8.997)\end{array}$ & $\begin{array}{l}-4.608 \\
(5.993)\end{array}$ & $\begin{array}{c}3.222 \\
(4.124)\end{array}$ & $\begin{array}{c}21.840^{* *} \\
(9.544)\end{array}$ \\
\hline $\begin{array}{l}\text { Prefeito \& } \\
\text { Governador }\end{array}$ & $\begin{array}{c}-23.959^{\star * *} \\
(4.776)\end{array}$ & $\begin{array}{c}-29.857^{\star * *} \\
(3.878)\end{array}$ & $\begin{array}{c}-14.484^{* * *} \\
(2.587)\end{array}$ & $\begin{array}{c}1.272 \\
(1.778)\end{array}$ & $\begin{array}{r}6.737^{*} \\
(4.117)\end{array}$ \\
\hline Idosos & $\begin{array}{l}13.649^{* * *} \\
(3.129)\end{array}$ & $\begin{array}{r}4.639^{*} \\
(2.541)\end{array}$ & $\begin{array}{l}5.397^{* * *} \\
(1.692)\end{array}$ & $\begin{array}{l}-6.312^{* * *} \\
(1.167)\end{array}$ & $\begin{array}{l}9.584^{* * *} \\
(2.701)\end{array}$ \\
\hline Urbanização & $\begin{array}{c}0.243 \\
(0.400)\end{array}$ & $\begin{array}{l}2.089^{* * *} \\
(0.324)\end{array}$ & $\begin{array}{l}1.731^{* * *} \\
(0.216)\end{array}$ & $\begin{array}{l}1.697^{* * *} \\
(0.149)\end{array}$ & $\begin{array}{l}-1.939^{* * *} \\
(0.344)\end{array}$ \\
\hline Jovens & $\begin{array}{l}-4.506^{* * *} \\
(1.044)\end{array}$ & $\begin{array}{c}-19.387^{* * *} \\
(0.848)\end{array}$ & $\begin{array}{l}-9.844^{* * *} \\
(0.566)\end{array}$ & $\begin{array}{l}-9.794^{* * *} \\
(0.389)\end{array}$ & $\begin{array}{l}16.352^{* * *} \\
(0.900)\end{array}$ \\
\hline População & $\begin{array}{l}126.683^{* * *} \\
(15.208)\end{array}$ & $\begin{array}{l}126.698^{* * *} \\
(12.348)\end{array}$ & $\begin{array}{l}46.446^{\star \star *} \\
(8.227)\end{array}$ & $\begin{array}{l}-9.976^{*} \\
(5.684)\end{array}$ & $\begin{array}{c}14.060 \\
(13.110)\end{array}$ \\
\hline Constante & $\begin{array}{c}-1066.740^{* * *} \\
(176.282)\end{array}$ & $\begin{array}{l}-578.620^{* * *} \\
(143.128)\end{array}$ & $\begin{array}{c}-194.379^{* *} \\
(95.372)\end{array}$ & $\begin{array}{l}294.821^{\star * *} \\
(65.849)\end{array}$ & $\begin{array}{l}-658.510^{\star * *} \\
(151.957)\end{array}$ \\
\hline $\mathrm{R}^{2}$ & 0.7767 & 0.3460 & 0.3565 & 0.3412 & 0.3941 \\
\hline Observações & 7267 & 7265 & 7244 & 7256 & 7256 \\
\hline Teste de Hausman & $\begin{array}{r}x^{2}=351,13 \\
\text { Prob }=0,00\end{array}$ & $\begin{array}{l}x^{2}=1364,51 \\
\text { Prob }=0,00\end{array}$ & $\begin{array}{r}x^{2}=688,27 \\
\text { Prob }=0,00\end{array}$ & $\begin{array}{r}x^{2}=399,44 \\
\text { Prob }=0,00\end{array}$ & $\begin{array}{l}x^{2}=150,28 \\
\text { Prob }=0,00\end{array}$ \\
\hline
\end{tabular}




\section{CONSIDERAÇÕES FINAIS}

Tendo os resultados analisados em mente, é possível detectar a presença (estatisticamente significante) da sensibilidade de algumas das variáveis consideradas perante o calendário eleitoral, notadamente no ano eleitoral de 1992. Assim sendo, os resultados permitem observar que, mesmo controlando pelos efeitos fixos intrínsecos a cada município e mesmo realizando um teste relativamente rigoroso (comparando a dummy do ano eleitoral somente em relação ao ano anterior e ao posterior), ainda é possível observar a influência estatisticamente significativa do fator "ano eleitoral" sobre o comportamento da despesa dos municípios considerados. Adicionalmente, os gráficos das dummies de ano sugerem a presença de ciclos econômicos determinando os gastos que não estão sob controle dos prefeitos, como no caso da despesa orçamentária, por exemplo. Contudo, o período disponível para tal análise é bastante limitado, impossibilitando uma avaliação mais profunda deste problema.

No que diz respeito ao teste para os partidos políticos, observa-se que boa parte dos resultados não apresenta significância estatística, o que pode corroborar uma das hipóteses presentes na literatura nacional da Ciência Política: ${ }^{19}$ a existência de uma baixa consistência ideológica por parte dos partidos políticos brasileiros, notadamente em esferas menos agregadas do poder político. De qualquer forma, os resultados obtidos demonstram que aos partidos PFL, PTB e ao grupo "outros partidos" estariam associadas as maiores diferenças de conduta na administração das despesas municipais, sugerindo assim um determinado grau de diferenciação entre os partidos políticos paulistas. Em termos mais específicos, observa-se que: (i) os maiores gastos agregados do PFL e do grupo "outros partidos" têm como origem seus maiores gastos em investimentos públicos e (ii) os maiores gastos agregados observados para o PTB têm como possível origem seus maiores gastos em transferências correntes - maiores transferências também são observadas nas gestões do PDS / PPB e do PMDB.

Como já citado anteriormente, é bastante curioso o comportamento das dummies de ano no caso das despesas de investimento e no caso das despesas correntes: observam-se evidências de um maior volume de recursos despendidos em gastos de consumo pelas prefeituras paulistas em detrimento de uma queda nos investimentos realizados, fato que pode prejudicar a obtenção de um crescimento sustentado por parte dos mesmos e ampliar (ainda mais) sua dependência em relação aos recursos oriundos de transferências do Estado e da União.

Os estudos realizados e analisados na revisão da literatura apresentam importantes elementos no que se refere à análise do comportamento da economia e sua relação com elementos de caráter (predominantemente) pertencente ao campo da teoria política. A inclusão destes novos elementos pode ser considerada de grande importância, pois a teoria econômica muitas vezes, por si só, não consegue justificar alguma forma de padrão cíclico no comportamento da economia. Aliada a estes novos conceitos, é possível desenvolver meios de se explicar a existência de resultados economicamente considerados subótimos e, principalmente, a persistência destes resultados ao longo do tempo, o que, somente à luz da teoria econômica, poderia ser considerado uma contradição.

Nesta situação, tornam-se relevantes, entre outras, as considerações existentes no trabalho de Nordhaus (1975): a primeira diz respeito ao fato de existir uma potencial relação positiva entre a necessidade de investimentos governamentais e a existência de interesses oportunistas da classe política, ou seja, pode-se considerar a hipótese de que a classe dos governantes pode extrair algum benefício político particular em função do atendimento das necessidades coletivas, influenciando assim, de maneira positiva, a probabilidade e a permanência dos ciclos eleitorais. Por sua vez, a segunda contribuição de Nordhaus (1975) diz respeito à necessidade de se minimizar potenciais

19 Ver, por exemplo, Mainwaring (1991), Avelino Filho (1994) e Samuels (1997). 
distorções econômicas associadas a um comportamento oportunista da classe política, com o desenvolvimento de mecanismos que transmitam as informações relevantes à classe dos eleitores. Esta questão também está de acordo com as considerações existentes em Rogoff (1990), e Rogoff e Sibert (1988), ao corroborar que um dos mecanismos fundamentais para minimizar os efeitos negativos dos ciclos eleitorais é justamente minimizar o problema de assimetria de informações entre a classe política e a classe dos eleitores: em um ambiente em que o problema de informação tende a ser não significante, maior tende a ser a capacidade dos eleitores para distinguir governantes competentes de governantes não competentes ou, então, distinguir propostas de governo concretas de propostas de gestão pública com viabilidade restrita.

\section{REFERÊNCIAS BIBLIOGRÁFICAS}

Alesina, Alberto. Macroeconomic policy in a two-party system as a repeated game. Quarterly Journal of Economics, n. 102, p. 651-678, 1987.

Avelino Filho, George. Clientelismo e política no Brasil. Novos Estudos, n. 38, p. 225-240, 1994.

Botelho, Ricardo. Determinantes do comportamento fiscal dos Estados brasileiros. 2002. Dissertação (Mestrado) - Instituto de Pesquisas Econômicas - Faculdade de Economia, Administração e Contabilidade - Universidade de São Paulo.

Cossio, Fernando Andrés Blanco. O comportamento fiscal dos Estados brasileiros e seus determinantes políticos. 1998. Mimeografado.

Drazen, Allan. Political economy in macroeconomics. Princeton: Ed. Princeton University Press, 2002.

Figueiredo, Argelina C.; Limongi Fernando. Incentivos eleitorais, partidos e política orçamentária. Dados, v. 45, n. 2, p. 303-344, 2002.

Giuberti, Ana Carolina. Lei de Responsabilidade Fiscal: efeitos sobre o gasto com pessoal dos municípios brasileiros. In: Anpec, 2005. Anais do XXXIII ${ }^{\circ}$ Encontro Nacional de Economia. Disponível em: $<$ http://www.anpec.org.br/encontro2005/artigos/A05A048.pdf>.

Hibbs Jr., Douglas A. Political parties and macroeconomic policy. American Political Science Review, n. 71, p. 1467-1487.

Hsiao, Cheng. Analysis of panel data. Cambridge: Ed. Cambridge University Press, 1986.

Libanio, Rita de Cássia. Indicadores sociais e desempenho nas eleições estaduais. 2003. Dissertação (Mestrado) - Instituto de Pesquisas Econômicas - Faculdade de Economia, Administração e Contabilidade - Universidade de São Paulo. (não publicada)

Lisboa, Marcos de Barros; Menezes-Filho, Naercio Aquino (org.). Microeconomia e sociedade no Brasil. Rio de Janeiro: Ed. Contra Capa, 2001.

Mainwaring, Scott. Políticos, partidos e sistemas eleitorais. Novos Estudos, n. 29, p. 34-58, 1991.

Mendes, Marcos; Rocha, Carlos Alexandre Amorim. O que reelege um prefeito? 2003. Mimeografado.

Meneguin, Fernando B.; Bugarin, Mauricio Soares. Reeleição e política fiscal: um estudo dos efeitos da reeleição nos gastos públicos. Economia Aplicada, v. 5, n. 3, 2001.

Menezes, Rafael. Impactos da lei de responsabilidade fiscal sobre os componentes de despesa dos municípios brasileiros. In: $\mathrm{X}^{\mathrm{o}}$ Prêmio Tesouro Nacional, 2005. Disponível em: <http://www.tesouro.fazenda.gov. br/Premio_TN/XPremio/conteudo_mono_pr10_tema4.html>. Acesso em: 20 out. 2006.

Nordhaus, William. The political business cycle. Review of Economic Studies, n. 42, p. 169-190, 1975.

Nunes, Selene P.; Nunes, Ricardo da C. Dois anos da Lei de Responsabilidade Fiscal do Brasil: uma avaliação dos resultados à luz do modelo do fundo comum. Departamento de Economia, Universidade de Brasília, 2003. (Série Textos para Discussão, n. 276) 
Persson, Torsten; Tabellini, Guido. Do electoral cycles differ across political systems? 2002. Disponível em: <http://papers.ssrn.com/sol3/papers.cfm?abstract_id=392643\#PaperDownload>. Acesso em: 23 out. 2003.

Petterson-Libdom, Per. A test of the rational electoral-cycle hypothesis. Disponível em: <http://www.courses. fas.harvard.edu/ gov3007/Electoralcycle.doc >. Acesso em: 20 set. 2002.

Rogoff, Kenneth; Sibert, Anne. Elections and macroeconomic policy cycles. Review of Economic Studies, n. 55, p. 1-16, 1988.

Rogoff, Kenneth. Equilibrium political budget cycles. The American Economic Review, n. 80, p. 21-36, 1990.

Romer, David. Advanced macroeconomics. Boston: Ed. McGraw-Hill, 2001.

Samuels, David. Determinantes do voto partidário em sistemas eleitorais centrados no candidato: evidências sobre o Brasil. Dados, v. 40, n. 3, 1997.

Shi, Min; Svensson, Jakob. Political business cycles in developed and developing countries. 2002. Disponível em: <http://www.iies.su.se/ svenssoj/pbcl.pdf>. Acesso em: 15 out. 2003. 


\section{APÊNDICES}

Tabela 4 - Testes de hipótese das dummies de tempo e de partido-baseados nos resultados da Tabela 2

\begin{tabular}{|c|c|c|c|c|c|}
\hline & $\begin{array}{c}\text { Despesa } \\
\text { orçamentária }\end{array}$ & $\begin{array}{l}\text { Despesa } \\
\text { corrente }\end{array}$ & $\begin{array}{c}\text { Despesa de } \\
\text { pessoal }\end{array}$ & $\begin{array}{l}\text { Transferências } \\
\text { correntes }\end{array}$ & Investimentos \\
\hline $\begin{array}{l}\text { dummy } 1991= \\
\text { dummy } 1992\end{array}$ & $\begin{array}{c}F(1,6671)=34.52 \\
\text { Prob }=0.0000\end{array}$ & $\begin{array}{c}F(1,6669)=52.95 \\
\text { Prob }=0.0000\end{array}$ & $\begin{array}{c}F(1,6648)=9.05 \\
\text { Prob }=0.0026\end{array}$ & $\begin{array}{c}F(1,6660)=2.95 \\
\text { Prob }=0.0861\end{array}$ & $\begin{array}{c}F(1,6660)=0.07 \\
\text { Prob }=0.7966\end{array}$ \\
\hline $\begin{array}{l}\text { dummy } 1992= \\
\text { dummy } 1993\end{array}$ & $\begin{array}{c}F(1,6671)=273.99 \\
\text { Prob }=0.0000\end{array}$ & $\begin{array}{c}F(1,6669)=92.54 \\
\text { Prob }=0.0000\end{array}$ & $\begin{array}{c}F(1,6648)=6.98 \\
\text { Prob }=0.0083\end{array}$ & $\begin{array}{c}F(1,6660)=0.34 \\
\text { Prob }=0.5624\end{array}$ & $\begin{array}{c}F(1,6660)=103.66 \\
\text { Prob }=0.0000\end{array}$ \\
\hline $\begin{array}{l}\text { dummy } 1995= \\
\text { dummy } 1996\end{array}$ & $\begin{array}{c}F(1,6671)=5.86 \\
\text { Prob }=0.0156\end{array}$ & $\begin{array}{c}F(1,6669)=78.69 \\
\text { Prob }=0.0000\end{array}$ & $\begin{array}{c}F(1,6648)=100.35 \\
\text { Prob }=0.0000\end{array}$ & $\begin{array}{c}F(1,6660)=6.68 \\
\text { Prob }=0.0098\end{array}$ & $\begin{array}{c}F(1,6660)=31.20 \\
\text { Prob }=0.0000\end{array}$ \\
\hline $\begin{array}{l}\text { dummy } 1996= \\
\text { dummy } 1997\end{array}$ & $\begin{array}{c}F(1,6671)=142.30 \\
\text { Prob }=0.0000\end{array}$ & $\begin{array}{c}F(1,6669)=17.38 \\
\text { Prob }=0.0000\end{array}$ & $\begin{array}{c}F(1,6648)=31.58 \\
\text { Prob }=0.0000\end{array}$ & $\begin{array}{c}F(1,6660)=1.35 \\
\text { Prob }=0.2454\end{array}$ & $\begin{array}{c}F(1,6660)=85.98 \\
\text { Prob }=0.0000\end{array}$ \\
\hline $\begin{array}{l}\text { dummy } 1999= \\
\text { dummy } 2000\end{array}$ & $\begin{array}{c}F(1,6671)=5.03 \\
\text { Prob }=0.0250\end{array}$ & $\begin{array}{c}F(1,6669)=1.55 \\
\text { Prob }=0.2133\end{array}$ & $\begin{array}{c}F(1,6648)=24.51 \\
\text { Prob }=0.0000\end{array}$ & $\begin{array}{c}F(1,6660)=57.52 \\
\text { Prob }=0.0000\end{array}$ & $\begin{array}{c}F(1,6660)=0.16 \\
\text { Prob }=0.6894\end{array}$ \\
\hline $\begin{array}{l}\text { dummy } 2000= \\
\text { dummy } 2001\end{array}$ & $\begin{array}{c}F(1,6671)=7.36 \\
\text { Prob }=0.0067\end{array}$ & $\begin{array}{c}F(1,6669)=0.56 \\
\text { Prob }=0.4555\end{array}$ & $\begin{array}{c}F(1,6648)=0.62 \\
\text { Prob }=0.4303\end{array}$ & $\begin{array}{c}F(1,6660)=10.19 \\
\text { Prob }=0.0014\end{array}$ & $\begin{array}{c}F(1,6660)=15.10 \\
\text { Prob }=0.0001\end{array}$ \\
\hline $\begin{array}{l}\text { PFL = } \\
P P B / P D S\end{array}$ & $\begin{array}{c}F(1,6671)=0.90 \\
\text { Prob }=0.3418\end{array}$ & $\begin{array}{c}F(1,6669)=1.79 \\
\text { Prob }=0.1811\end{array}$ & $\begin{array}{c}F(1,6648)=7.28 \\
\text { Prob }=0.0070\end{array}$ & $\begin{array}{c}F(1,6660)=2.37 \\
\text { Prob }=0.1240\end{array}$ & $\begin{array}{c}F(1,6660)=4.55 \\
\text { Prob }=0.0330\end{array}$ \\
\hline $\begin{array}{l}\text { PFL = } \\
\text { PMDB }\end{array}$ & $\begin{array}{c}F(1,6671)=7.12 \\
\text { Prob }=0.0076\end{array}$ & $\begin{array}{c}F(1,6669)=0.09 \\
\text { Prob }=0.7585\end{array}$ & $\begin{array}{c}F(1,6648)=0.29 \\
\text { Prob }=0.5915\end{array}$ & $\begin{array}{c}F(1,6660)=1.20 \\
\text { Prob }=0.2741\end{array}$ & $\begin{array}{c}F(1,6660)=5.48 \\
\text { Prob }=0.0192\end{array}$ \\
\hline $\begin{array}{l}\text { PFL = } \\
\text { PSDB }\end{array}$ & $\begin{array}{c}F(1,6671)=0.87 \\
\text { Prob }=0.3498\end{array}$ & $\begin{array}{c}F(1,6669)=0.04 \\
\text { Prob }=0.8492\end{array}$ & $\begin{array}{c}F(1,6648)=2.14 \\
\text { Prob }=0.1440\end{array}$ & $\begin{array}{c}F(1,6660)=0.00 \\
\text { Prob }=0.9782\end{array}$ & $\begin{array}{c}F(1,6660)=1.50 \\
\text { Prob }=0.2208\end{array}$ \\
\hline PFL = PTB & $\begin{array}{c}F(1,6671)=1.76 \\
\text { Prob }=0.1846\end{array}$ & $\begin{array}{c}F(1,6669)=2.80 \\
\text { Prob }=0.0942\end{array}$ & $\begin{array}{c}F(1,6648)=6.99 \\
\text { Prob }=0.0082\end{array}$ & $\begin{array}{c}F(1,6660)=2.67 \\
\text { Prob }=0.1022\end{array}$ & $\begin{array}{c}F(1,6660)=0.33 \\
\text { Prob }=0.5635\end{array}$ \\
\hline $\begin{array}{l}\text { PFL = } \\
\text { OUTROS PARTIDOS }\end{array}$ & $\begin{array}{c}F(1,6671)=0.13 \\
\text { Prob }=0.7145\end{array}$ & $\begin{array}{c}F(1,6669)=0.27 \\
\text { Prob }=0.6066\end{array}$ & $\begin{array}{c}F(1,6648)=1.74 \\
\text { Prob }=0.1868\end{array}$ & $\begin{array}{c}F(1,6660)=0.06 \\
\text { Prob }=0.8049\end{array}$ & $\begin{array}{c}F(1,6660)=0.08 \\
\text { Prob }=0.7794\end{array}$ \\
\hline PPB $/$ PDS = PMDB & $\begin{array}{c}F(1,6671)=1.68 \\
\text { Prob }=0.1946\end{array}$ & $\begin{array}{c}F(1,6669)=2.45 \\
\text { Prob }=0.1172\end{array}$ & $\begin{array}{c}F(1,6648)=4.82 \\
\text { Prob }=0.0282\end{array}$ & $\begin{array}{c}F(1,6660)=0.35 \\
\text { Prob }=0.5531\end{array}$ & $\begin{array}{c}F(1,6660)=0.02 \\
\text { Prob }=0.8946\end{array}$ \\
\hline $\begin{array}{l}\text { PPB } / \text { PDS = } \\
\text { PSDB }\end{array}$ & $\begin{array}{c}F(1,6671)=0.01 \\
\text { Prob }=0.9219\end{array}$ & $\begin{array}{c}F(1,6669)=0.74 \\
\text { Prob }=0.3909\end{array}$ & $\begin{array}{c}F(1,6648)=0.60 \\
\text { Prob }=0.4376\end{array}$ & $\begin{array}{c}F(1,6660)=1.34 \\
\text { Prob }=0.2477\end{array}$ & $\begin{array}{c}F(1,6660)=0.30 \\
\text { Prob }=0.5813\end{array}$ \\
\hline PPB / PDS = PTB & $\begin{array}{c}F(1,6671)=3.64 \\
\text { Prob }=0.0564\end{array}$ & $\begin{array}{c}F(1,6669)=0.06 \\
\text { Prob }=0.8129\end{array}$ & $\begin{array}{c}F(1,6648)=0.02 \\
\text { Prob }=0.8985\end{array}$ & $\begin{array}{c}F(1,6660)=0.00 \\
\text { Prob }=0.9742\end{array}$ & $\begin{array}{c}F(1,6660)=1.82 \\
\text { Prob }=0.1778\end{array}$ \\
\hline $\begin{array}{l}\text { PPB / PDS = } \\
\text { OUTROS PARTIDOS }\end{array}$ & $\begin{array}{c}F(1,6671)=0.42 \\
\text { Prob }=0.5152\end{array}$ & $\begin{array}{c}F(1,6669)=3.05 \\
\text { Prob }=0.0808\end{array}$ & $\begin{array}{c}F(1,6648)=2.62 \\
\text { Prob }=0.1057\end{array}$ & $\begin{array}{c}F(1,6660)=2.99 \\
\text { Prob }=0.0837\end{array}$ & $\begin{array}{c}F(1,6660)=5.51 \\
\text { Prob }=0.0190\end{array}$ \\
\hline PMDB = PSDB & $\begin{array}{c}F(1,6671)=1.94 \\
\text { Prob }=0.1638\end{array}$ & $\begin{array}{c}F(1,6669)=0.31 \\
\text { Prob }=0.5754\end{array}$ & $\begin{array}{c}F(1,6648)=2.04 \\
\text { Prob }=0.1531\end{array}$ & $\begin{array}{c}F(1,6660)=1.10 \\
\text { Prob }=0.2946\end{array}$ & $\begin{array}{c}F(1,6660)=0.46 \\
\text { Prob }=0.4972\end{array}$ \\
\hline PMDB = PTB & $\begin{array}{c}F(1,6671)=11.64 \\
\text { Prob }=0.0006\end{array}$ & $\begin{array}{c}F(1,6669)=3.24 \\
\text { Prob }=0.0718\end{array}$ & $\begin{array}{c}F(1,6648)=4.04 \\
\text { Prob }=0.0446\end{array}$ & $\begin{array}{c}F(1,6660)=0.38 \\
\text { Prob }=0.5373\end{array}$ & $\begin{array}{c}F(1,6660)=1.91 \\
\text { Prob }=0.1672\end{array}$ \\
\hline $\begin{array}{l}\text { PMDB = OUTROS } \\
\text { PARTIDOS }\end{array}$ & $\begin{array}{c}F(1,6671)=5.45 \\
\text { Prob }=0.0196\end{array}$ & $\begin{array}{c}F(1,6669)=0.03 \\
\text { Prob }=0.8545\end{array}$ & $\begin{array}{c}F(1,6648)=0.53 \\
\text { Prob }=0.4687\end{array}$ & $\begin{array}{c}F(1,6660)=1.79 \\
\text { Prob }=0.1815\end{array}$ & $\begin{array}{c}F(1,6660)=6.88 \\
\text { Prob }=0.0088\end{array}$ \\
\hline PSDB = PTB & $\begin{array}{c}F(1,6671)=3.24 \\
\text { Prob }=0.0720\end{array}$ & $\begin{array}{c}F(1,6669)=1.13 \\
\text { Prob }=0.2871\end{array}$ & $\begin{array}{c}F(1,6648)=0.43 \\
\text { Prob }=0.5098\end{array}$ & $\begin{array}{c}F(1,6660)=1.39 \\
\text { Prob }=0.2387\end{array}$ & $\begin{array}{c}F(1,6660)=0.43 \\
\text { Prob }=0.5139\end{array}$ \\
\hline $\begin{array}{l}\text { PSDB = OUTROS } \\
\text { PARTIDOS }\end{array}$ & $\begin{array}{c}F(1,6671)=0.47 \\
\text { Prob }=0.4924\end{array}$ & $\begin{array}{c}F(1,6669)=0.31 \\
\text { Prob }=0.5760\end{array}$ & $\begin{array}{c}F(1,6648)=0.29 \\
\text { Prob }=0.5897\end{array}$ & $\begin{array}{c}F(1,6660)=0.04 \\
\text { Prob }=0.8388\end{array}$ & $\begin{array}{c}F(1,6660)=2.07 \\
\text { Prob }=0.1501\end{array}$ \\
\hline $\begin{array}{l}\text { PTB = OUTROS } \\
\text { PARTIDOS }\end{array}$ & $\begin{array}{c}F(1,6671)=2.52 \\
\text { Prob }=0.1127\end{array}$ & $\begin{array}{c}F(1,6669)=4.18 \\
\text { Prob }=0.0409\end{array}$ & $\begin{array}{c}F(1,6648)=2.21 \\
\text { Prob }=0.1368\end{array}$ & $\begin{array}{c}F(1,6660)=3.19 \\
\text { Prob }=0.0739\end{array}$ & $\begin{array}{c}F(1,6660)=0.62 \\
\text { Prob }=0.4300\end{array}$ \\
\hline
\end{tabular}


Gráficos das dummies de ano e de partido - conforme Tabela 2

Dummies de ano - despesa orçamentária

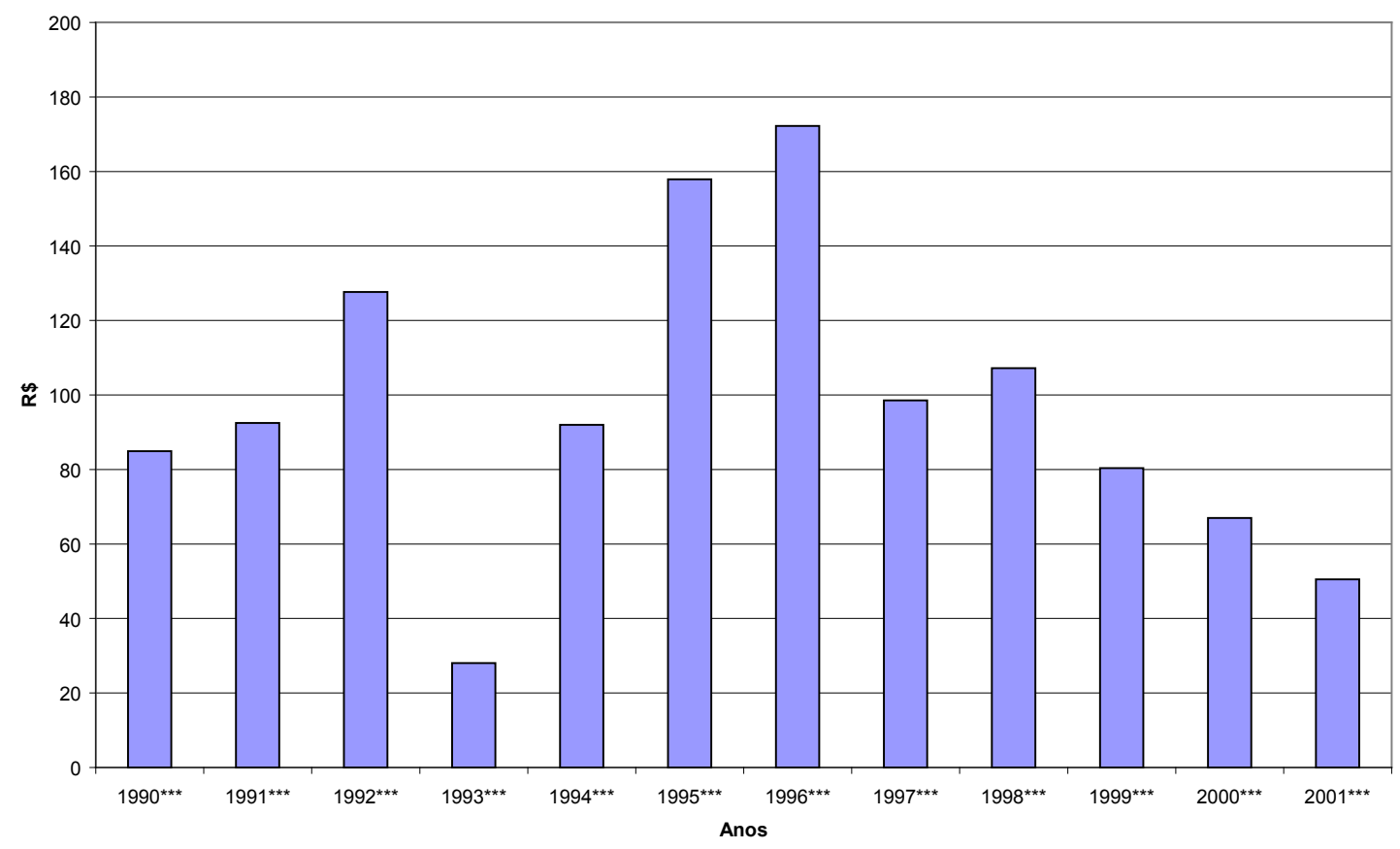

Dummies de ano - despesa corrente

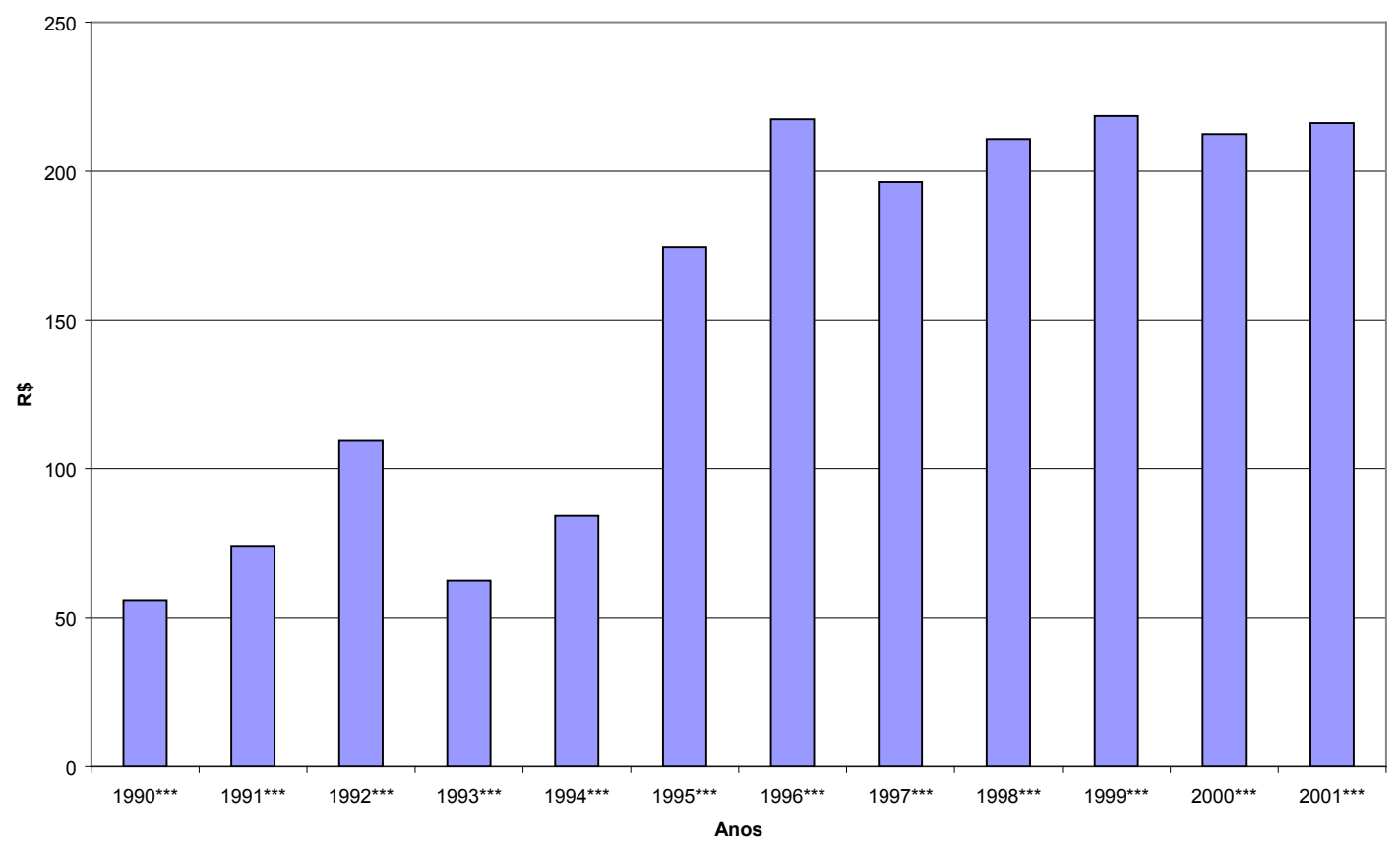


Dummies de ano - despesa de pessoal

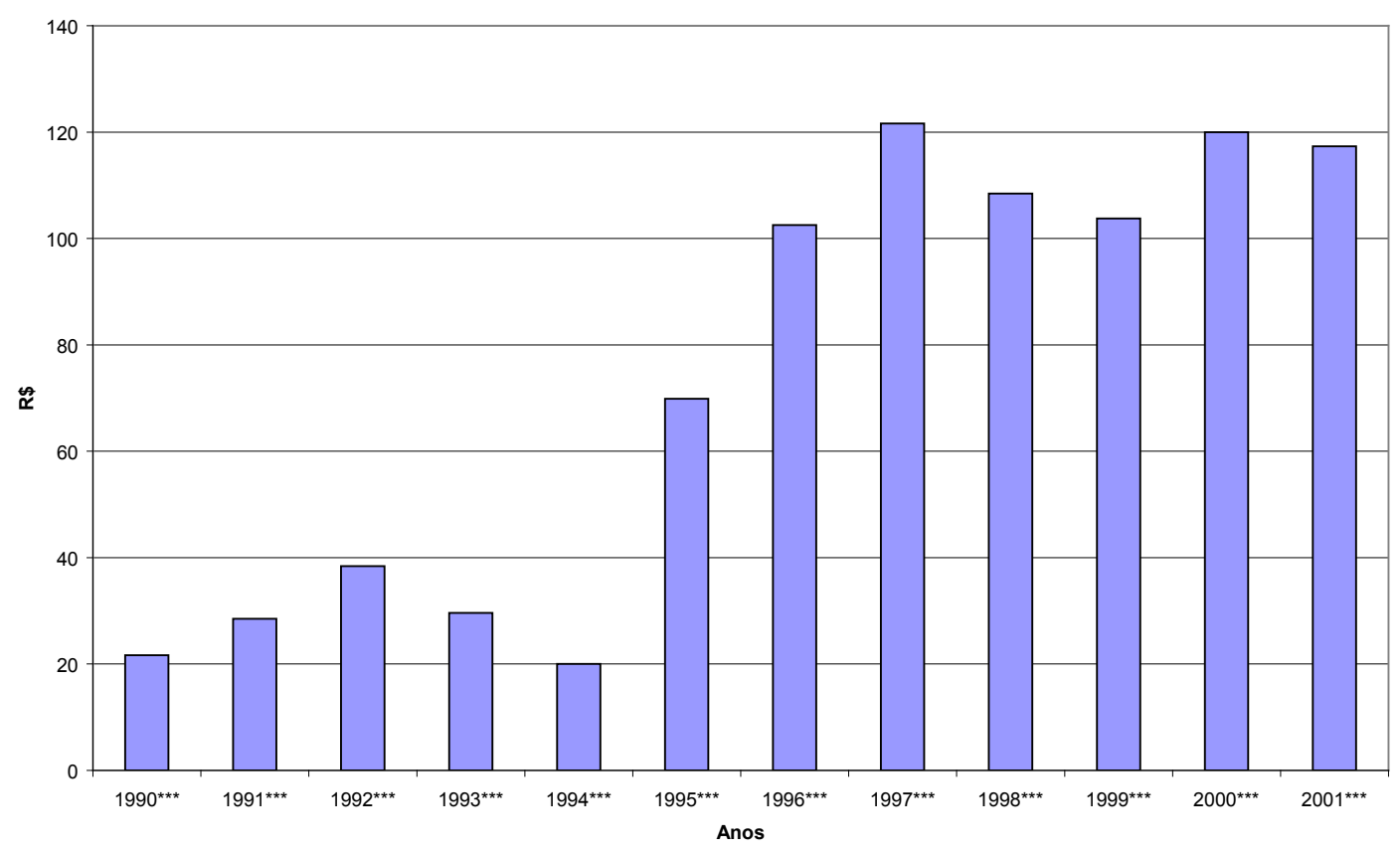

\section{Dummies de ano - transferências correntes}

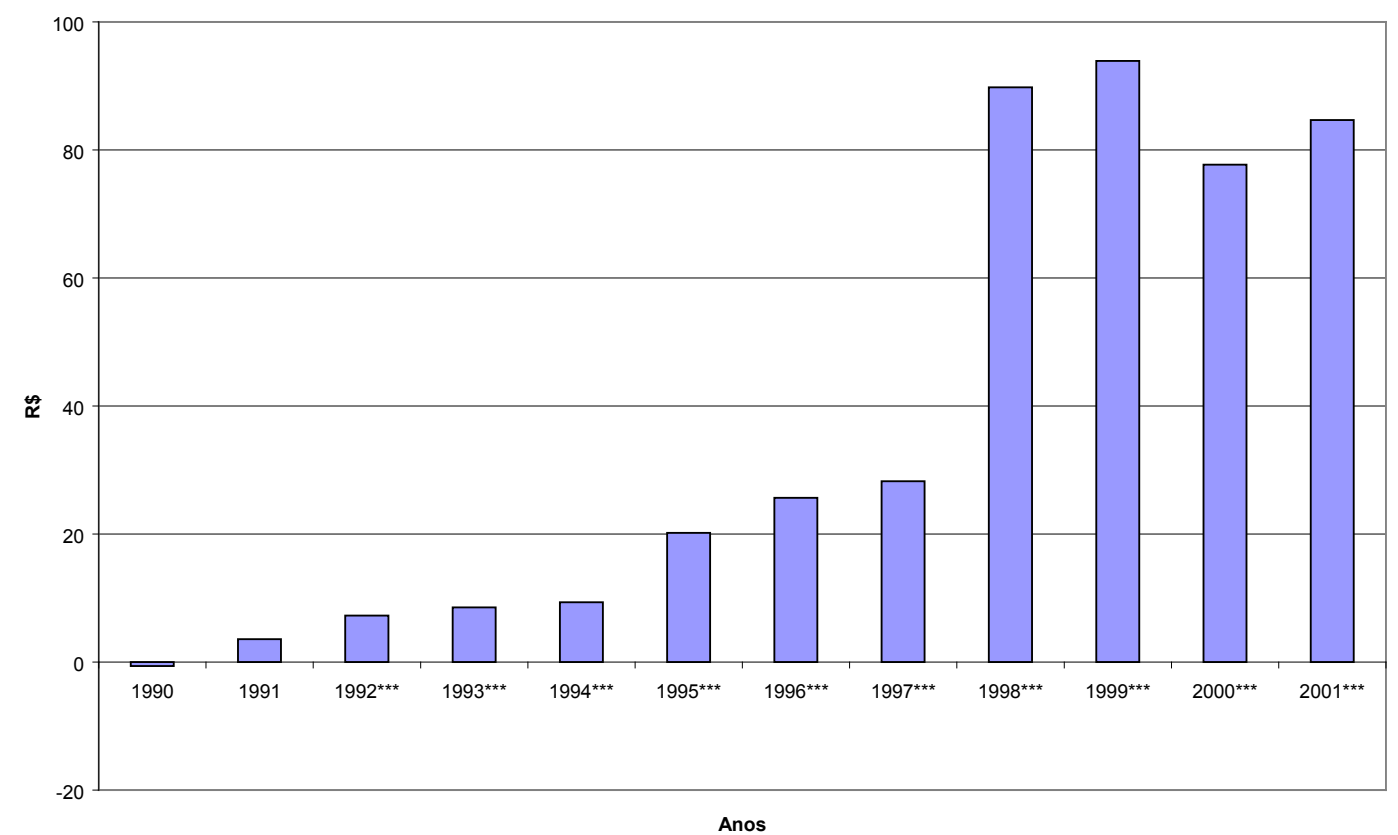




\section{Dummies de ano - investimentos}

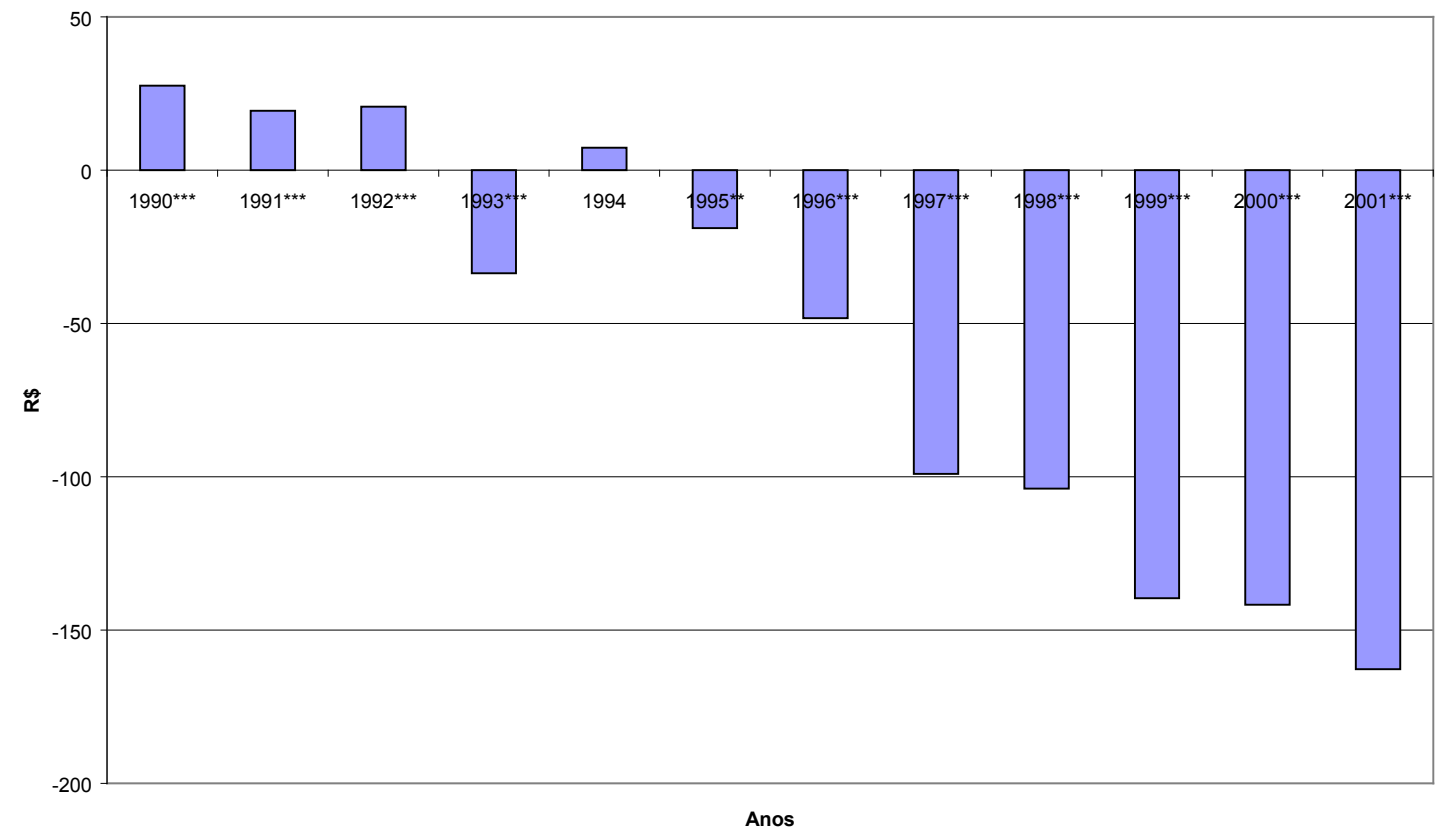

Dummies de partido - despesa orçamentária

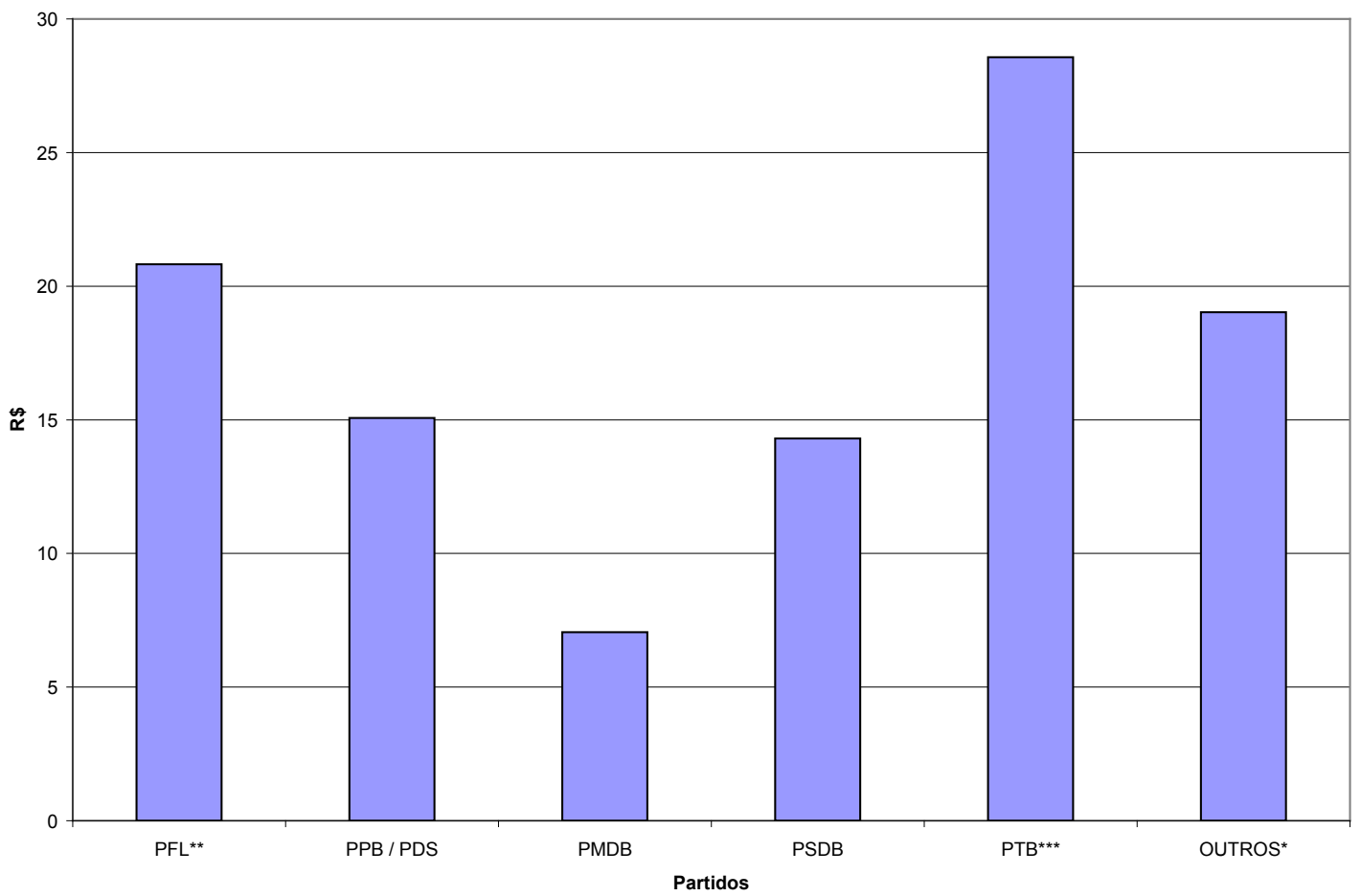


Dummies de partido - despesas correntes

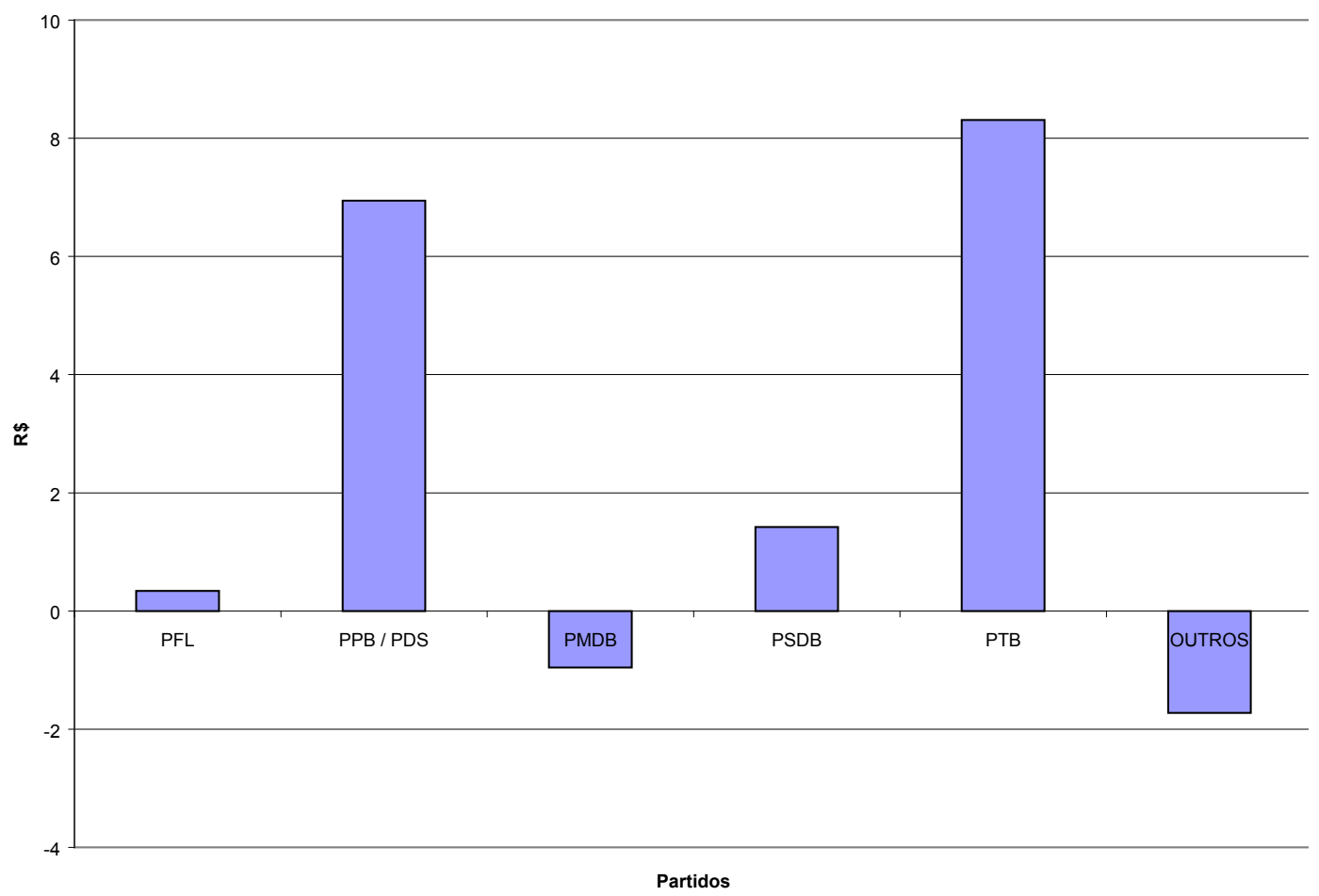

Dummies de partido - despesa de pessoal

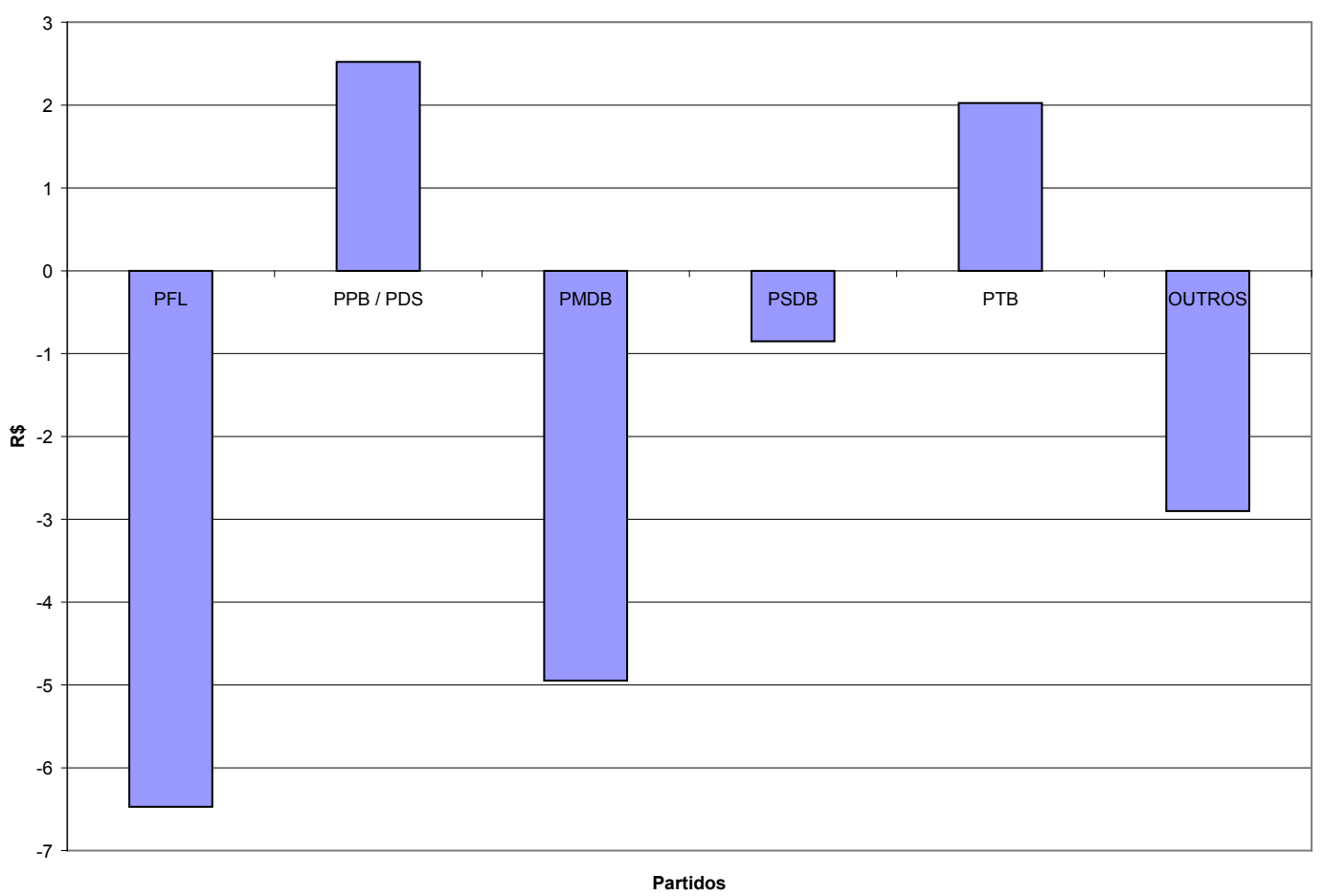




\section{Dummies de partido - transferências correntes}

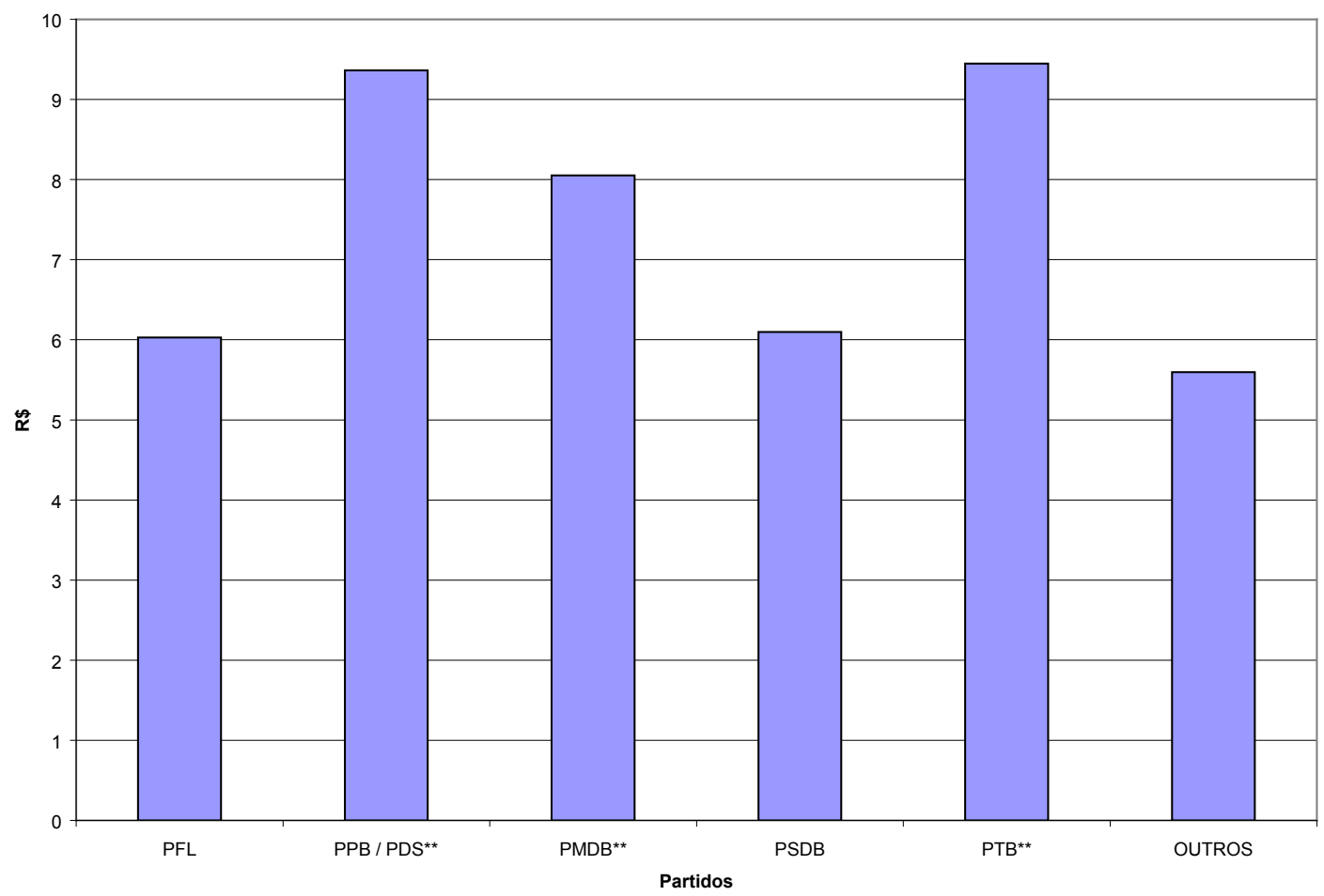

\section{Dummies de partido - investimentos}

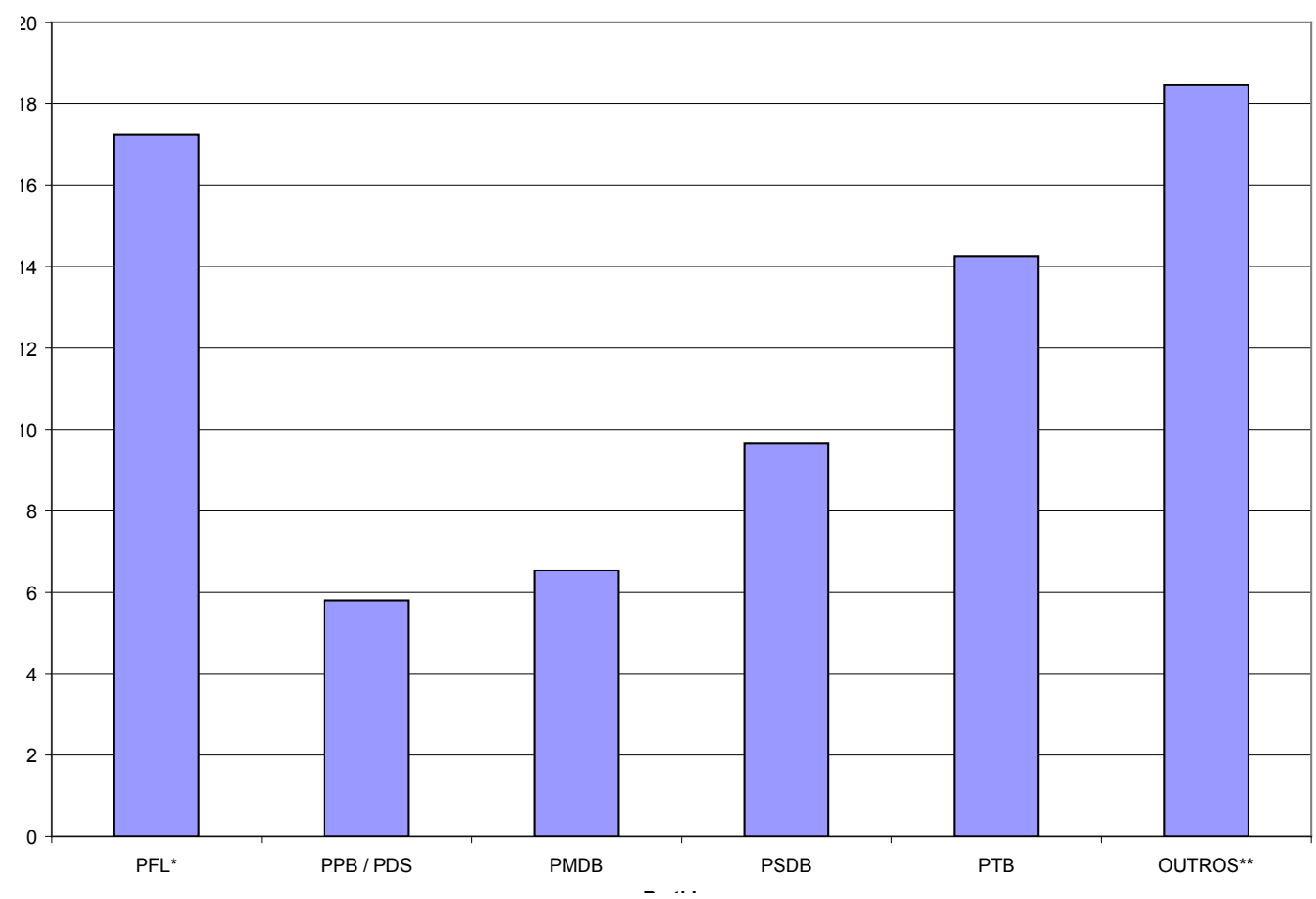


Tabela 5 - Resultados das regressões - receita orçamentária - modelo sem variáveis políticas - método de efeitos fixos

\begin{tabular}{|c|c|c|c|c|c|}
\hline & $\begin{array}{c}\text { Despesa } \\
\text { orçamentária }\end{array}$ & $\begin{array}{l}\text { Despesa } \\
\text { corrente }\end{array}$ & $\begin{array}{c}\text { Despesa de } \\
\text { pessoal }\end{array}$ & $\begin{array}{l}\text { Transferências } \\
\text { correntes }\end{array}$ & Investimentos \\
\hline $\begin{array}{l}\text { Receita } \\
\text { orçamentária }\end{array}$ & $\begin{array}{l}0.942^{\star * *} \\
(0.006)\end{array}$ & $\begin{array}{l}0.517^{\star \star \star *} \\
(0.005)\end{array}$ & $\begin{array}{l}0.216^{* * *} \\
(0.004)\end{array}$ & $\begin{array}{l}0.063^{* * *} \\
(0.003)\end{array}$ & $\begin{array}{l}0.403^{* * *} \\
(0.006)\end{array}$ \\
\hline Dummy 1990 & $\begin{array}{l}69.011^{* * *} \\
(5.325)\end{array}$ & $\begin{array}{l}47.120^{* * *} \\
(4.635)\end{array}$ & $\begin{array}{l}18.438^{* * *} \\
(3.283)\end{array}$ & $\begin{array}{l}-1.376 \\
(2.153)\end{array}$ & $\begin{array}{l}20.635^{* * *} \\
(5.151)\end{array}$ \\
\hline Dummy 1991 & $\begin{array}{l}60.792^{\star * *} \\
(5.745)\end{array}$ & $\begin{array}{l}56.702^{* * *} \\
(5.000)\end{array}$ & $\begin{array}{l}21.128^{\star \star *} \\
(3.542)\end{array}$ & $\begin{array}{c}1.407 \\
(2.322)\end{array}$ & $\begin{array}{c}5.741 \\
(5.558)\end{array}$ \\
\hline Dummy 1992 & $\begin{array}{c}110.033^{\star * \star} \\
(6.414)\end{array}$ & $\begin{array}{l}99.970^{* \star *} \\
(5.585)\end{array}$ & $\begin{array}{l}33.704^{\star \star *} \\
(3.965)\end{array}$ & $\begin{array}{l}5.646^{* *} \\
(2.593)\end{array}$ & $\begin{array}{l}13.211^{* *} \\
(6.212)\end{array}$ \\
\hline Dummy 1993 & $\begin{array}{l}18.296^{* *} \\
(7.186)\end{array}$ & $\begin{array}{l}57.163^{\star * *} \\
(6.254)\end{array}$ & $\begin{array}{l}27.214^{* \star *} \\
(4.440)\end{array}$ & $\begin{array}{l}7.518^{* * *} \\
(2.904)\end{array}$ & $\begin{array}{c}-37.618^{\star * *} \\
(6.953)\end{array}$ \\
\hline Dummy 1994 & $\begin{array}{l}74.607^{* * *} \\
(8.129)\end{array}$ & $\begin{array}{l}74.797^{* * *} \\
(7.075)\end{array}$ & $\begin{array}{l}16.325^{* * *} \\
(5.013)\end{array}$ & $\begin{array}{l}8.081^{* *} \\
(3.285)\end{array}$ & $\begin{array}{c}0.006 \\
(7.866)\end{array}$ \\
\hline Dummy 1995 & $\begin{array}{c}108.449^{* * *} \\
(9.049)\end{array}$ & $\begin{array}{c}148.691^{* * *} \\
(7.876)\end{array}$ & $\begin{array}{l}59.745^{\star \star *} \\
(5.581)\end{array}$ & $\begin{array}{l}17.520^{\star \star \star} \\
(3.657)\end{array}$ & $\begin{array}{c}-41.081^{* * *} \\
(8.757)\end{array}$ \\
\hline Dummy 1996 & $\begin{array}{l}121.566^{* * *} \\
(10.058)\end{array}$ & $\begin{array}{c}191.008^{* * *} \\
(8.754)\end{array}$ & $\begin{array}{l}92.270^{* * *} \\
(6.204)\end{array}$ & $\begin{array}{l}23.023^{* * *} \\
(4.065)\end{array}$ & $\begin{array}{c}-71.036^{* * *} \\
(9.734)\end{array}$ \\
\hline Dummy 1997 & $\begin{array}{l}57.585^{\star * *} \\
(10.895)\end{array}$ & $\begin{array}{c}174.074^{* * *} \\
(9.482)\end{array}$ & $\begin{array}{c}113.636^{* * *} \\
(6.721)\end{array}$ & $\begin{array}{l}25.148^{* * *} \\
(4.403)\end{array}$ & $\begin{array}{c}-116.934^{* * *} \\
(10.543)\end{array}$ \\
\hline Dummy 1998 & $\begin{array}{l}59.892^{* * *} \\
(11.804)\end{array}$ & $\begin{array}{l}185.067^{* * *} \\
(10.274)\end{array}$ & $\begin{array}{l}99.847^{* * *} \\
(7.285)\end{array}$ & $\begin{array}{l}86.922^{* * *} \\
(4.769)\end{array}$ & $\begin{array}{c}-124.686^{* * *} \\
(11.425)\end{array}$ \\
\hline Dummy 1999 & $\begin{array}{l}44.806^{\star \star *} \\
(12.658)\end{array}$ & $\begin{array}{l}199.188^{* * *} \\
(11.017)\end{array}$ & $\begin{array}{l}97.612^{\star \star \star} \\
(7.807)\end{array}$ & $\begin{array}{c}91.662^{* * \star} \\
(5.114)\end{array}$ & $\begin{array}{c}-155.343^{* * *} \\
(12.249)\end{array}$ \\
\hline Dummy 2000 & $\begin{array}{l}35.460^{* * *} \\
(13.565)\end{array}$ & $\begin{array}{l}195.369^{* * *} \\
(11.806)\end{array}$ & $\begin{array}{c}115.124^{* * *} \\
(8.367)\end{array}$ & $\begin{array}{l}75.982^{* * *} \\
(5.480)\end{array}$ & $\begin{array}{c}-155.853^{* * *} \\
(13.128)\end{array}$ \\
\hline Dummy 2001 & $\begin{array}{c}21.338 \\
(14.525)\end{array}$ & $\begin{array}{l}200.607^{\star * *} \\
(12.642)\end{array}$ & $\begin{array}{c}113.045^{\star * *} \\
(8.959)\end{array}$ & $\begin{array}{l}82.869^{* * *} \\
(5.871)\end{array}$ & $\begin{array}{c}-176.064^{* * *} \\
(14.060)\end{array}$ \\
\hline Idosos & $\begin{array}{l}-4.008 \\
(2.756)\end{array}$ & $\begin{array}{l}-3.638 \\
(2.398)\end{array}$ & $\begin{array}{c}2.449 \\
(1.699)\end{array}$ & $\begin{array}{l}3.897^{\star \star *} \\
(1.114)\end{array}$ & $\begin{array}{c}0.266 \\
(2.672)\end{array}$ \\
\hline Urbanização & $\begin{array}{c}0.775^{* *} \\
(0.349)\end{array}$ & $\begin{array}{l}0.760^{* *} \\
(0.304)\end{array}$ & $\begin{array}{l}0.974^{* * *} \\
(0.215)\end{array}$ & $\begin{array}{l}1.059^{* * *} \\
(0.141)\end{array}$ & $\begin{array}{l}-0.092 \\
(0.338)\end{array}$ \\
\hline Jovens & $\begin{array}{c}3.784^{* *} \\
(1.761)\end{array}$ & $\begin{array}{l}7.755^{* * *} \\
(1.533)\end{array}$ & $\begin{array}{l}4.525^{\star \star *} \\
(1.086)\end{array}$ & $\begin{array}{l}2.629^{\star * *} \\
(0.711)\end{array}$ & $\begin{array}{l}-2.763 \\
(1.705)\end{array}$ \\
\hline População & $\begin{array}{r}23.437^{*} \\
(14.045)\end{array}$ & $\begin{array}{l}-11.918 \\
(12.224)\end{array}$ & $\begin{array}{c}-22.807^{\star * *} \\
(8.663)\end{array}$ & $\begin{array}{c}-41.158^{* * *} \\
(5.696)\end{array}$ & $\begin{array}{l}51.485^{\star * *} \\
(13.597)\end{array}$ \\
\hline Constante & $\begin{array}{l}-371.281^{* *} \\
(147.675)\end{array}$ & $\begin{array}{c}-48.763 \\
(128.528)\end{array}$ & $\begin{array}{l}54.684 \\
(91.086)\end{array}$ & $\begin{array}{l}198.646^{* \star *} \\
(59.838)\end{array}$ & $\begin{array}{l}-506.590^{* \star *} \\
(142.994)\end{array}$ \\
\hline$R^{2}$ & 0.9375 & 0.8666 & 0.7329 & 0.1806 & 0.5183 \\
\hline Observações & 7267 & 7265 & 7244 & 7256 & 7256 \\
\hline Teste de Hausman & $\begin{array}{r}x^{2}=203.85 \\
\text { Prob }=0.00\end{array}$ & $\begin{array}{r}x^{2}=868.23 \\
\text { Prob }=0.00\end{array}$ & $\begin{array}{r}x^{2}=727.03 \\
\text { Prob }=0.00\end{array}$ & $\begin{array}{r}x^{2}=191.08 \\
\text { Prob }=0.00\end{array}$ & $\begin{array}{r}x^{2}=271.29 \\
\text { Prob }=0.00\end{array}$ \\
\hline
\end{tabular}


Tabela 6 - Resultados das regressões - receita orçamentária - modelo com variáveis políticas - método de efeitos fixos

\begin{tabular}{|c|c|c|c|c|c|}
\hline & $\begin{array}{c}\text { Despesa } \\
\text { orçamentária }\end{array}$ & $\begin{array}{l}\text { Despesa } \\
\text { corrente }\end{array}$ & $\begin{array}{c}\text { Despesa } \\
\text { de pessoal }\end{array}$ & $\begin{array}{c}\text { Transferências } \\
\text { correntes }\end{array}$ & Investimentos \\
\hline $\begin{array}{l}\text { Receita } \\
\text { orçamentária }\end{array}$ & $\begin{array}{l}0.941^{* * *} \\
(0.006)\end{array}$ & $\begin{array}{l}0.517^{* * *} \\
(0.005)\end{array}$ & $\begin{array}{l}0.216^{* * *} \\
(0.004)\end{array}$ & $\begin{array}{l}0.063^{* \star \star} \\
(0.003)\end{array}$ & $\begin{array}{l}0.401^{* \star *} \\
(0.006)\end{array}$ \\
\hline Dummy 1990 & $\begin{array}{l}69.019^{* \star *} \\
(5.323)\end{array}$ & $\begin{array}{l}47.031^{* \star *} \\
(4.634)\end{array}$ & $\begin{array}{l}18.396^{* * *} \\
(3.281)\end{array}$ & $\begin{array}{l}-1.397 \\
(2.152)\end{array}$ & $\begin{array}{l}20.735^{\star * *} \\
(5.150)\end{array}$ \\
\hline Dummy 1991 & $\begin{array}{l}60.685^{\star \star \star} \\
(5.744)\end{array}$ & $\begin{array}{l}56.566^{* * *} \\
(5.001)\end{array}$ & $\begin{array}{l}21.079^{\star * *} \\
(3.541)\end{array}$ & $\begin{array}{c}1.379 \\
(2.322)\end{array}$ & $\begin{array}{l}5.803 \\
(5.558)\end{array}$ \\
\hline Dummy 1992 & $\begin{array}{c}109.764^{* * *} \\
(6.414)\end{array}$ & $\begin{array}{l}99.801^{* * *} \\
(5.587)\end{array}$ & $\begin{array}{l}33.676^{* \star *} \\
(3.964)\end{array}$ & $\begin{array}{l}5.624^{* *} \\
(2.594)\end{array}$ & $\begin{array}{l}13.172^{* *} \\
(6.214)\end{array}$ \\
\hline Dummy 1993 & $\begin{array}{l}19.218^{* * *} \\
(7.221)\end{array}$ & $\begin{array}{l}57.474^{\star \star \star} \\
(6.287)\end{array}$ & $\begin{array}{l}27.118^{\star * *} \\
(4.461)\end{array}$ & $\begin{array}{l}7.639^{* * *} \\
(2.919)\end{array}$ & $\begin{array}{c}-37.346^{* \star *} \\
(6.988)\end{array}$ \\
\hline Dummy 1994 & $\begin{array}{l}75.492^{* * *} \\
(8.159)\end{array}$ & $\begin{array}{l}75.050^{\star * *} \\
(7.104)\end{array}$ & $\begin{array}{l}16.178^{* * *} \\
(5.031)\end{array}$ & $\begin{array}{l}8.191^{* *} \\
(3.298)\end{array}$ & $\begin{array}{c}0.306 \\
(7.897)\end{array}$ \\
\hline Dummy 1995 & $\begin{array}{c}110.836^{* * *} \\
(9.238)\end{array}$ & $\begin{array}{c}148.562^{* * *} \\
(8.043)\end{array}$ & $\begin{array}{l}59.646^{* \star *} \\
(5.697)\end{array}$ & $\begin{array}{l}17.389^{* \star *} \\
(3.734)\end{array}$ & $\begin{array}{c}-39.044^{* \star *} \\
(8.941)\end{array}$ \\
\hline Dummy 1996 & $\begin{array}{l}123.952^{* * *} \\
(10.229)\end{array}$ & $\begin{array}{c}190.822^{* * *} \\
(8.906)\end{array}$ & $\begin{array}{l}92.147^{\star \star *} \\
(6.308)\end{array}$ & $\begin{array}{l}22.875^{\star \star *} \\
(4.134)\end{array}$ & $\begin{array}{c}-68.940^{\star \star *} \\
(9.901)\end{array}$ \\
\hline Dummy 1997 & $\begin{array}{l}56.062^{* * *} \\
(11.052)\end{array}$ & $\begin{array}{c}173.005^{* * *} \\
(9.622)\end{array}$ & $\begin{array}{c}112.248^{* * *} \\
(6.816)\end{array}$ & $\begin{array}{l}25.606^{* \star *} \\
(4.467)\end{array}$ & $\begin{array}{c}-117.189^{* * *} \\
(10.697)\end{array}$ \\
\hline Dummy 1998 & $\begin{array}{l}58.344^{* \star *} \\
(11.956)\end{array}$ & $\begin{array}{l}183.882^{* * *} \\
(10.409)\end{array}$ & $\begin{array}{l}98.410^{* \star *} \\
(7.377)\end{array}$ & $\begin{array}{l}87.335^{\star \star *} \\
(4.832)\end{array}$ & $\begin{array}{c}-124.828^{\star * *} \\
(11.573)\end{array}$ \\
\hline Dummy 1999 & $\begin{array}{l}43.081^{\star * \star} \\
(12.806)\end{array}$ & $\begin{array}{l}197.988^{* \star *} \\
(11.149)\end{array}$ & $\begin{array}{l}96.213^{\star \star *} \\
(7.897)\end{array}$ & $\begin{array}{l}92.080^{\star \star \star} \\
(5.175)\end{array}$ & $\begin{array}{c}-155.606^{\star \star \star} \\
(12.394)\end{array}$ \\
\hline Dummy 2000 & $\begin{array}{c}33.668^{* *} \\
(13.708)\end{array}$ & $\begin{array}{l}194.090^{* * *} \\
(11.934)\end{array}$ & $\begin{array}{c}113.703^{* * *} \\
(8.453)\end{array}$ & $\begin{array}{l}76.379^{* * *} \\
(5.539)\end{array}$ & $\begin{array}{c}-156.074^{* * *} \\
(13.269)\end{array}$ \\
\hline Dummy 2001 & $\begin{array}{c}19.619 \\
(14.635)\end{array}$ & $\begin{array}{l}199.155^{* * *} \\
(12.741)\end{array}$ & $\begin{array}{c}111.481^{* * *} \\
(9.024)\end{array}$ & $\begin{array}{l}83.416^{* \star *} \\
(5.916)\end{array}$ & $\begin{array}{c}-176.063^{* * *} \\
(14.169)\end{array}$ \\
\hline PFL & $\begin{array}{c}6.337 \\
(9.166)\end{array}$ & $\begin{array}{l}-7.635 \\
(7.980)\end{array}$ & $\begin{array}{l}-9.410^{*} \\
(5.650)\end{array}$ & $\begin{array}{c}5.328 \\
(3.699)\end{array}$ & $\begin{array}{l}11.005 \\
(8.870)\end{array}$ \\
\hline PPB / PDS & $\begin{array}{c}2.741 \\
(9.668)\end{array}$ & $\begin{array}{c}0.170 \\
(8.417)\end{array}$ & $\begin{array}{l}-0.304 \\
(5.962)\end{array}$ & $\begin{array}{l}8.539^{* *} \\
(3.902)\end{array}$ & $\begin{array}{c}0.548 \\
(9.356)\end{array}$ \\
\hline PMDB & $\begin{array}{l}-2.579 \\
(9.295)\end{array}$ & $\begin{array}{l}-6.251 \\
(8.093)\end{array}$ & $\begin{array}{l}-7.079 \\
(5.731)\end{array}$ & $\begin{array}{l}7.459^{* *} \\
(3.752)\end{array}$ & $\begin{array}{l}2.398 \\
(8.997)\end{array}$ \\
\hline PSDB & $\begin{array}{c}6.935 \\
(10.053)\end{array}$ & $\begin{array}{l}-2.629 \\
(8.752)\end{array}$ & $\begin{array}{l}-2.329 \\
(6.200)\end{array}$ & $\begin{array}{c}5.778 \\
(4.058)\end{array}$ & $\begin{array}{c}6.487 \\
(9.730)\end{array}$ \\
\hline PTB & $\begin{array}{l}13.947 \\
(9.495)\end{array}$ & $\begin{array}{l}0.264 \\
(8.267)\end{array}$ & $\begin{array}{l}-1.026 \\
(5.854)\end{array}$ & $\begin{array}{l}8.650^{* *} \\
(3.833)\end{array}$ & $\begin{array}{l}7.973 \\
(9.189)\end{array}$ \\
\hline OUTROS & $\begin{array}{c}4.582 \\
(9.197)\end{array}$ & $\begin{array}{l}-9.669 \\
(8.007)\end{array}$ & $\begin{array}{l}-6.042 \\
(5.670)\end{array}$ & $\begin{array}{c}4.780 \\
(3.713)\end{array}$ & $\begin{array}{l}12.267 \\
(8.900)\end{array}$ \\
\hline $\begin{array}{l}\text { Prefeito e } \\
\text { Governador }\end{array}$ & $\begin{array}{c}3.895 \\
(4.263)\end{array}$ & $\begin{array}{l}-0.751 \\
(3.711)\end{array}$ & $\begin{array}{c}0.281 \\
(2.633)\end{array}$ & $\begin{array}{l}-0.554 \\
(1.721)\end{array}$ & $\begin{array}{c}4.269 \\
(4.128)\end{array}$ \\
\hline Idosos & $\begin{array}{l}-4.324 \\
(2.760)\end{array}$ & $\begin{array}{l}-3.731 \\
(2.403)\end{array}$ & $\begin{array}{c}2.468 \\
(1.702)\end{array}$ & $\begin{array}{l}3.879^{\star \star *} \\
(1.116)\end{array}$ & $\begin{array}{c}0.128 \\
(2.677)\end{array}$ \\
\hline Urbanização & $\begin{array}{l}0.777^{* *} \\
(0.349)\end{array}$ & $\begin{array}{l}0.776^{* *} \\
(0.304)\end{array}$ & $\begin{array}{l}0.981^{* * *} \\
(0.215)\end{array}$ & $\begin{array}{l}1.074^{* * *} \\
(0.141)\end{array}$ & $\begin{array}{l}-0.109 \\
(0.338)\end{array}$ \\
\hline Jovens & $\begin{array}{l}3.595^{* *} \\
(1.766)\end{array}$ & $\begin{array}{l}7.662^{* * *} \\
(1.538)\end{array}$ & $\begin{array}{l}4.520^{\star * *} \\
(1.089)\end{array}$ & $\begin{array}{l}2.630^{* * *} \\
(0.713)\end{array}$ & $\begin{array}{l}-2.812^{*} \\
(1.710)\end{array}$ \\
\hline População & $\begin{array}{c}23.396^{*} \\
(14.058)\end{array}$ & $\begin{array}{l}-12.050 \\
(12.239)\end{array}$ & $\begin{array}{c}-22.243^{* * *} \\
(8.669)\end{array}$ & $\begin{array}{c}-40.933^{* * *} \\
(5.703)\end{array}$ & $\begin{array}{l}51.549^{* \star *} \\
(13.612)\end{array}$ \\
\hline Constante & $\begin{array}{l}-367.405^{\star *} \\
(148.328)\end{array}$ & $\begin{array}{c}-39.762 \\
(129.136)\end{array}$ & $\begin{array}{c}54.283 \\
(91.470)\end{array}$ & $\begin{array}{l}188.911^{* * *} \\
(60.117)\end{array}$ & $\begin{array}{l}-510.802^{* * *} \\
(143.667)\end{array}$ \\
\hline$R^{2}$ & 0.9373 & 0.8672 & 0.7359 & 0.1817 & 0.518 \\
\hline Observações & 7267 & 7265 & 7244 & 7256 & 7256 \\
\hline Teste de Hausman & $\begin{array}{l}x^{2}=225.15 \\
\text { Prob }=0.00\end{array}$ & $\begin{array}{l}{ }^{2}=1250.91 \\
\text { rob }=0.00\end{array}$ & $\begin{array}{l}x^{2}=641.26 \\
\text { Prob }=0.00\end{array}$ & $\begin{array}{l}x^{2}=245.52 \\
\text { Prob }=0.00\end{array}$ & $\begin{array}{l}x^{2}=361.04 \\
\text { Prob }=0.00\end{array}$ \\
\hline
\end{tabular}


Tabela 7 - Resultados das regressões - receita orçamentária - teste da LRF - método de efeitos fixos

\begin{tabular}{|c|c|c|c|c|c|}
\hline & $\begin{array}{c}\text { Despesa } \\
\text { orçamentária }\end{array}$ & $\begin{array}{l}\text { Despesa } \\
\text { corrente }\end{array}$ & $\begin{array}{l}\text { Despesa de } \\
\text { pessoal }\end{array}$ & $\begin{array}{l}\text { Transferências } \\
\text { correntes }\end{array}$ & Investimentos \\
\hline $\begin{array}{l}\text { Receita } \\
\text { orçamentária }\end{array}$ & $\begin{array}{l}0.945^{\star \star \star} \\
(0.006)\end{array}$ & $\begin{array}{l}0.537^{\star \star \star} \\
(0.006)\end{array}$ & $\begin{array}{l}0.229^{* \star *} \\
(0.004)\end{array}$ & $\begin{array}{l}0.078^{\star \star *} \\
(0.003)\end{array}$ & $\begin{array}{l}0.384^{\star \star \star} \\
(0.006)\end{array}$ \\
\hline Dummy LRF & $\begin{array}{c}-43.840^{* * *} \\
(4.051)\end{array}$ & $\begin{array}{c}-18.925^{\star * *} \\
(3.499)\end{array}$ & $\begin{array}{c}1.029 \\
(2.461)\end{array}$ & $\begin{array}{r}3.117^{*} \\
(1.718)\end{array}$ & $\begin{array}{c}-20.493^{\star * *} \\
(3.864)\end{array}$ \\
\hline PFL & $\begin{array}{c}6.962 \\
(9.760)\end{array}$ & $\begin{array}{l}-6.571 \\
(8.430)\end{array}$ & $\begin{array}{l}-8.737 \\
(5.927)\end{array}$ & $\begin{array}{r}7.316^{*} \\
(4.136)\end{array}$ & $\begin{array}{l}10.794 \\
(9.288)\end{array}$ \\
\hline PPB / PDS & $\begin{array}{c}5.546 \\
(10.291)\end{array}$ & $\begin{array}{c}1.115 \\
(8.889)\end{array}$ & $\begin{array}{l}-0.466 \\
(6.252)\end{array}$ & $\begin{array}{r}8.056^{*} \\
(4.361)\end{array}$ & $\begin{array}{c}2.413 \\
(9.794)\end{array}$ \\
\hline PMDB & $\begin{array}{l}17.340^{*} \\
(9.813)\end{array}$ & $\begin{array}{c}5.667 \\
(8.476)\end{array}$ & $\begin{array}{l}-4.492 \\
(5.960)\end{array}$ & $\begin{array}{c}0.151 \\
(4.159)\end{array}$ & $\begin{array}{c}9.656 \\
(9.339)\end{array}$ \\
\hline PSDB & $\begin{array}{c}14.117 \\
(10.557)\end{array}$ & $\begin{array}{l}24.152^{* * *} \\
(9.118)\end{array}$ & $\begin{array}{l}16.545^{\star * *} \\
(6.414)\end{array}$ & $\begin{array}{l}10.554^{* *} \\
(4.474)\end{array}$ & $\begin{array}{l}-13.997 \\
(10.048)\end{array}$ \\
\hline PTB & $\begin{array}{c}16.063 \\
(10.119)\end{array}$ & $\begin{array}{c}0.323 \\
(8.739)\end{array}$ & $\begin{array}{l}-1.396 \\
(6.146)\end{array}$ & $\begin{array}{l}10.081^{* *} \\
(4.288)\end{array}$ & $\begin{array}{l}10.384 \\
(9.629)\end{array}$ \\
\hline OUTROS & $\begin{array}{c}6.550 \\
(9.793)\end{array}$ & $\begin{array}{r}-11.454 \\
(8.458)\end{array}$ & $\begin{array}{l}-7.970 \\
(5.948)\end{array}$ & $\begin{array}{c}2.222 \\
(4.150)\end{array}$ & $\begin{array}{l}16.016^{*} \\
(9.319)\end{array}$ \\
\hline $\begin{array}{l}\text { Prefeito \& } \\
\text { Governador }\end{array}$ & $\begin{array}{c}-15.899^{\star * \star} \\
(4.221)\end{array}$ & $\begin{array}{c}-25.270^{\star \star \star} \\
(3.646)\end{array}$ & $\begin{array}{c}-12.517^{\star \star *} \\
(2.568)\end{array}$ & $\begin{array}{c}1.916 \\
(1.789)\end{array}$ & $\begin{array}{l}10.030^{* *} \\
(4.019)\end{array}$ \\
\hline Idosos & $\begin{array}{l}12.153^{* * *} \\
(2.765)\end{array}$ & $\begin{array}{c}3.764 \\
(2.388)\end{array}$ & $\begin{array}{l}5.108^{\star \star \star} \\
(1.679)\end{array}$ & $\begin{array}{l}-6.356^{* * *} \\
(1.174)\end{array}$ & $\begin{array}{l}8.983^{* * *} \\
(2.636)\end{array}$ \\
\hline Urbanização & $\begin{array}{l}1.012^{* * *} \\
(0.353)\end{array}$ & $\begin{array}{l}2.518^{\star * *} \\
(0.305)\end{array}$ & $\begin{array}{l}1.946^{* * *} \\
(0.214)\end{array}$ & $\begin{array}{l}1.790^{* * *} \\
(0.150)\end{array}$ & $\begin{array}{l}-1.624^{* * *} \\
(0.336)\end{array}$ \\
\hline Jovens & $\begin{array}{l}2.992^{* \star *} \\
(0.931)\end{array}$ & $\begin{array}{c}-15.079^{* \star \star} \\
(0.804)\end{array}$ & $\begin{array}{l}-8.175^{\star \star \star} \\
(0.566)\end{array}$ & $\begin{array}{l}-9.334^{\star * *} \\
(0.395)\end{array}$ & $\begin{array}{l}19.383^{\star \star \star} \\
(0.886)\end{array}$ \\
\hline População & $\begin{array}{l}53.463^{\star * *} \\
(13.474)\end{array}$ & $\begin{array}{l}84.813^{* * \star} \\
(11.637)\end{array}$ & $\begin{array}{l}29.571^{* * *} \\
(8.185)\end{array}$ & $\begin{array}{c}-15.134^{\star * *} \\
(5.734)\end{array}$ & $\begin{array}{l}-15.686 \\
(12.832)\end{array}$ \\
\hline Constante & $\begin{array}{l}-694.150^{\star * *} \\
(155.813)\end{array}$ & $\begin{array}{l}-366.018^{\star * \star} \\
(134.571)\end{array}$ & $\begin{array}{r}-106.929 \\
(94.668)\end{array}$ & $\begin{array}{l}323.033^{\star * \star} \\
(66.279)\end{array}$ & $\begin{array}{l}-506.578^{\star \star *} \\
(148.392)\end{array}$ \\
\hline $\mathrm{R}^{2}$ & 0.9100 & 0.5218 & 0.4666 & 0.3320 & 0.3750 \\
\hline Observações & 7267 & 7265 & 7244 & 7256 & 7256 \\
\hline Teste de Hausman & $\begin{array}{l}x^{2}=193.78 \\
\text { Prob }=0.00\end{array}$ & $\begin{array}{l}x^{2}=542.00 \\
\text { Prob }=0.00\end{array}$ & $\begin{array}{r}x^{2}=504.94 \\
\text { Prob }=0.00\end{array}$ & $\begin{array}{l}x^{2}=371.57 \\
\text { Prob }=0.00\end{array}$ & $\begin{array}{l}x^{2}=392.62 \\
\text { Prob }=0.00\end{array}$ \\
\hline
\end{tabular}


Tabela 8 - Resultados das regressões - receita de transferências governamentais - modelo sem variáveis políticas - método de efeitos fixos

\begin{tabular}{|c|c|c|c|c|c|}
\hline & $\begin{array}{c}\text { Despesa } \\
\text { orçamentária }\end{array}$ & $\begin{array}{l}\text { Despesa } \\
\text { corrente }\end{array}$ & $\begin{array}{c}\text { Despesa de } \\
\text { pessoal }\end{array}$ & $\begin{array}{c}\text { Transferências } \\
\text { correntes }\end{array}$ & Investimentos \\
\hline $\begin{array}{l}\text { Receita de } \\
\text { transferências }\end{array}$ & $\begin{array}{l}1.030^{\star \star \star} \\
(0.009)\end{array}$ & $\begin{array}{l}0.598^{\star \star *} \\
(0.006)\end{array}$ & $\begin{array}{l}0.264^{* \star *} \\
(0.004)\end{array}$ & $\begin{array}{l}0.080^{* \star *} \\
(0.003)\end{array}$ & $\begin{array}{l}0.407^{\star \star \star} \\
(0.008)\end{array}$ \\
\hline Dummy 1990 & $\begin{array}{l}37.078^{* \star *} \\
(6.343)\end{array}$ & $\begin{array}{l}26.671^{\star * *} \\
(4.699)\end{array}$ & $\begin{array}{l}8.651^{* * *} \\
(3.234)\end{array}$ & $\begin{array}{l}-4.451^{* *} \\
(2.145)\end{array}$ & $\begin{array}{r}9.897^{*} \\
(5.580)\end{array}$ \\
\hline Dummy 1991 & $\begin{array}{l}42.538^{\star \star \star} \\
(6.818)\end{array}$ & $\begin{array}{l}45.404^{\star \star *} \\
(5.051)\end{array}$ & $\begin{array}{l}15.840^{\star * *} \\
(3.476)\end{array}$ & $\begin{array}{l}-0.222 \\
(2.305)\end{array}$ & $\begin{array}{l}-0.791 \\
(5.999)\end{array}$ \\
\hline Dummy 1992 & $\begin{array}{l}71.041^{* * *} \\
(7.595)\end{array}$ & $\begin{array}{l}78.860^{\star * *} \\
(5.630)\end{array}$ & $\begin{array}{l}24.973^{* * *} \\
(3.882)\end{array}$ & $\begin{array}{c}3.133 \\
(2.569)\end{array}$ & $\begin{array}{l}-3.728 \\
(6.691)\end{array}$ \\
\hline Dummy 1993 & $\begin{array}{l}10.850 \\
(8.519)\end{array}$ & $\begin{array}{l}53.977^{* * *} \\
(6.311)\end{array}$ & $\begin{array}{l}26.390^{* * *} \\
(4.352)\end{array}$ & $\begin{array}{l}7.311^{* *} \\
(2.880)\end{array}$ & $\begin{array}{c}-41.704^{* * *} \\
(7.496)\end{array}$ \\
\hline Dummy 1994 & $\begin{array}{l}59.919^{\star \star \star} \\
(9.641)\end{array}$ & $\begin{array}{l}65.993^{\star \star *} \\
(7.142)\end{array}$ & $\begin{array}{l}12.259^{\star *} \\
(4.915)\end{array}$ & $\begin{array}{l}6.856^{* \star} \\
(3.259)\end{array}$ & $\begin{array}{l}-5.548 \\
(8.483)\end{array}$ \\
\hline Dummy 1995 & $\begin{array}{l}75.448^{* * *} \\
(10.758)\end{array}$ & $\begin{array}{c}126.481^{* * *} \\
(7.970)\end{array}$ & $\begin{array}{l}48.655^{\star \star *} \\
(5.486)\end{array}$ & $\begin{array}{l}13.984^{* \star *} \\
(3.637)\end{array}$ & $\begin{array}{c}-51.133^{* * \star} \\
(9.467)\end{array}$ \\
\hline Dummy 1996 & $\begin{array}{c}108.456^{\star * *} \\
(11.939)\end{array}$ & $\begin{array}{c}179.935^{\star * *} \\
(8.845)\end{array}$ & $\begin{array}{l}85.911^{* * *} \\
(6.089)\end{array}$ & $\begin{array}{l}20.889^{* * *} \\
(4.036)\end{array}$ & $\begin{array}{l}-72.820^{* * *} \\
(10.507)\end{array}$ \\
\hline Dummy 1997 & $\begin{array}{l}25.480^{* \star} \\
(12.937)\end{array}$ & $\begin{array}{c}152.866^{\star \star \star} \\
(9.584)\end{array}$ & $\begin{array}{c}103.174^{* * \star} \\
(6.599)\end{array}$ & $\begin{array}{l}21.831^{* \star *} \\
(4.373)\end{array}$ & $\begin{array}{c}-127.114^{\star * \star} \\
(11.385)\end{array}$ \\
\hline Dummy 1998 & $\begin{array}{l}65.032^{* * *} \\
(14.001)\end{array}$ & $\begin{array}{l}182.393^{\star * \star} \\
(10.373)\end{array}$ & $\begin{array}{l}95.925^{\star \star \star} \\
(7.145)\end{array}$ & $\begin{array}{l}85.489^{* * *} \\
(4.733)\end{array}$ & $\begin{array}{c}-117.098^{\star \star \star} \\
(12.323)\end{array}$ \\
\hline Dummy 1999 & $\begin{array}{c}7.397 \\
(15.044)\end{array}$ & $\begin{array}{l}172.779^{\star * *} \\
(11.145)\end{array}$ & $\begin{array}{l}83.954^{* * *} \\
(7.673)\end{array}$ & $\begin{array}{l}87.250^{\star * *} \\
(5.085)\end{array}$ & $\begin{array}{c}-165.527^{* * *} \\
(13.238)\end{array}$ \\
\hline Dummy 2000 & $\begin{array}{c}15.293 \\
(16.109)\end{array}$ & $\begin{array}{l}177.985^{\star * \star} \\
(11.934)\end{array}$ & $\begin{array}{c}105.033^{\star * *} \\
(8.216)\end{array}$ & $\begin{array}{l}72.585^{\star \star \star} \\
(5.444)\end{array}$ & $\begin{array}{c}-158.229^{\star * \star} \\
(14.177)\end{array}$ \\
\hline Dummy 2001 & $\begin{array}{l}-30.020^{*} \\
(17.267)\end{array}$ & $\begin{array}{l}165.750^{\star \star *} \\
(12.792)\end{array}$ & $\begin{array}{l}95.499^{\star * *} \\
(8.807)\end{array}$ & $\begin{array}{l}77.245^{\star \star \star} \\
(5.838)\end{array}$ & $\begin{array}{c}-191.402^{\star * \star} \\
(15.200)\end{array}$ \\
\hline Idosos & $\begin{array}{l}-6.686^{* *} \\
(3.269)\end{array}$ & $\begin{array}{l}-5.759^{* *} \\
(2.422)\end{array}$ & $\begin{array}{c}1.295 \\
(1.667)\end{array}$ & $\begin{array}{l}3.510^{\star * *} \\
(1.106)\end{array}$ & $\begin{array}{l}-0.234 \\
(2.883)\end{array}$ \\
\hline Urbanização & $\begin{array}{l}-1.640^{* * *} \\
(0.415)\end{array}$ & $\begin{array}{l}-0.693^{* *} \\
(0.307)\end{array}$ & $\begin{array}{c}0.316 \\
(0.211)\end{array}$ & $\begin{array}{l}0.857^{* * *} \\
(0.140)\end{array}$ & $\begin{array}{l}-0.992^{* \star *} \\
(0.365)\end{array}$ \\
\hline Jovens & $\begin{array}{l}-3.673^{*} \\
(2.088)\end{array}$ & $\begin{array}{l}3.661^{* *} \\
(1.547)\end{array}$ & $\begin{array}{l}2.809^{* * *} \\
(1.065)\end{array}$ & $\begin{array}{l}2.127^{\star \star \star} \\
(0.705)\end{array}$ & $\begin{array}{l}-5.945^{\star \star \star} \\
(1.837)\end{array}$ \\
\hline População & $\begin{array}{l}37.530^{\star \star} \\
(16.650)\end{array}$ & $\begin{array}{c}-7.639 \\
(12.335)\end{array}$ & $\begin{array}{c}-21.565^{\star \star} \\
(8.490)\end{array}$ & $\begin{array}{c}-41.321^{* * *} \\
(5.649)\end{array}$ & $\begin{array}{l}60.938^{* \star \star} \\
(14.658)\end{array}$ \\
\hline Constante & $\begin{array}{c}45.453 \\
(175.249)\end{array}$ & $\begin{array}{r}213.614^{*} \\
(129.831)\end{array}$ & $\begin{array}{l}169.663^{*} \\
(89.358)\end{array}$ & $\begin{array}{l}237.351^{* * *} \\
(59.406)\end{array}$ & $\begin{array}{l}-362.374^{* *} \\
(154.315)\end{array}$ \\
\hline $\mathrm{R}^{2}$ & 0.8455 & 0.7912 & 0.6516 & 0.1604 & 0.4511 \\
\hline Observações & 7267 & 7265 & 7244 & 7256 & 7256 \\
\hline Teste de Hausman & $\begin{array}{r}x^{2}=230.68 \\
\text { Prob }=0.00\end{array}$ & $\begin{array}{r}x^{2}=487.44 \\
\text { Prob }=0.00\end{array}$ & $\begin{array}{r}x^{2}=353.06 \\
\text { Prob }=0.00\end{array}$ & $\begin{array}{r}x^{2}=172.92 \\
\text { Prob }=0.00\end{array}$ & $\begin{array}{r}x^{2}=80.03 \\
\text { Prob }=0.00\end{array}$ \\
\hline
\end{tabular}


Tabela 9 - Resultados das regressões - receita de transferências governamentais - modelo com variáveis políticas - método de efeitos fixos

\begin{tabular}{|c|c|c|c|c|c|}
\hline & $\begin{array}{c}\text { Despesa } \\
\text { orçamentária }\end{array}$ & $\begin{array}{l}\text { Despesa } \\
\text { corrente }\end{array}$ & $\begin{array}{c}\text { Despesa } \\
\text { de pessoal }\end{array}$ & $\begin{array}{c}\text { Transferências } \\
\text { correntes }\end{array}$ & Investimentos \\
\hline $\begin{array}{l}\text { Receita de } \\
\text { transferências }\end{array}$ & $\begin{array}{r}1.027^{* * *} \\
(0.009)\end{array}$ & $\begin{array}{r}0.597^{* * *} \\
(0.006)\end{array}$ & $\begin{array}{r}0.264^{* * *} \\
(0.004)\end{array}$ & $\begin{array}{r}0.080^{* * *} \\
(0.003)\end{array}$ & $\begin{array}{r}0.405^{\star \star *} \\
(0.008)\end{array}$ \\
\hline Dummy 1990 & $\begin{array}{r}37.282^{\star * *} \\
(6.330)\end{array}$ & $\begin{array}{r}26.695^{\star * *} \\
(4.700)\end{array}$ & $\begin{array}{r}8.658^{\star \star \star} \\
(3.233)\end{array}$ & $\begin{array}{r}-4.461^{* *} \\
(2.145)\end{array}$ & $\begin{array}{l}10.062^{*} \\
(5.573)\end{array}$ \\
\hline Dummy 1991 & $\begin{array}{r}42.606^{* * *} \\
(6.805)\end{array}$ & $\begin{array}{r}45.381^{* * *} \\
(5.053)\end{array}$ & $\begin{array}{r}15.845^{* * *} \\
(3.475)\end{array}$ & $\begin{array}{l}-0.234 \\
(2.305)\end{array}$ & $\begin{array}{l}-0.675 \\
(5.991)\end{array}$ \\
\hline Dummy 1992 & $\begin{array}{r}70.959^{* * *} \\
(7.583)\end{array}$ & $\begin{array}{r}78.790^{* * *} \\
(5.634)\end{array}$ & $\begin{array}{r}24.991^{* * *} \\
(3.882)\end{array}$ & $\begin{array}{r}3.125 \\
(2.570)\end{array}$ & $\begin{array}{l}-3.681 \\
(6.684)\end{array}$ \\
\hline Dummy 1993 & $\begin{array}{l}11.493 \\
(8.547)\end{array}$ & $\begin{array}{r}54.092^{* * *} \\
(6.346)\end{array}$ & $\begin{array}{r}26.186^{* * *} \\
(4.373)\end{array}$ & $\begin{array}{l}7.401^{* *} \\
(2.895)\end{array}$ & $\begin{array}{r}-41.507^{* * *} \\
(7.525)\end{array}$ \\
\hline Dummy 1994 & $\begin{array}{r}60.502^{* \star *} \\
(9.661)\end{array}$ & $\begin{array}{r}66.057^{* * *} \\
(7.173)\end{array}$ & $\begin{array}{r}12.027^{* *} \\
(4.934)\end{array}$ & $\begin{array}{l}6.937^{\star *} \\
(3.272)\end{array}$ & $\begin{array}{l}-5.357 \\
(8.506)\end{array}$ \\
\hline Dummy 1995 & $\begin{array}{r}82.707^{\star * *} \\
(10.962)\end{array}$ & $\begin{array}{r}128.866^{\star \star *} \\
(8.139)\end{array}$ & $\begin{array}{r}49.567^{\star * \star} \\
(5.600)\end{array}$ & $\begin{array}{r}14.121^{* * *} \\
(3.712)\end{array}$ & $\begin{array}{r}-46.873^{\star * *} \\
(9.653)\end{array}$ \\
\hline Dummy 1996 & $\begin{array}{r}115.741^{* * *} \\
(12.120)\end{array}$ & $\begin{array}{r}182.304^{\star * *} \\
(8.999)\end{array}$ & $\begin{array}{r}86.822^{* \star *} \\
(6.191)\end{array}$ & $\begin{array}{r}21.018^{\star * *} \\
(4.105)\end{array}$ & $\begin{array}{r}-68.509^{* * *} \\
(10.672)\end{array}$ \\
\hline Dummy 1997 & $\begin{array}{l}26.903^{\star *} \\
(13.100)\end{array}$ & $\begin{array}{r}153.591^{* * *} \\
(9.727)\end{array}$ & $\begin{array}{r}102.567^{* * *} \\
(6.692)\end{array}$ & $\begin{array}{r}22.543^{\star \star *} \\
(4.436)\end{array}$ & $\begin{array}{r}-126.295^{\star \star *} \\
(11.535)\end{array}$ \\
\hline Dummy 1998 & $\begin{array}{r}66.551^{\star * *} \\
(14.155)\end{array}$ & $\begin{array}{r}183.149^{* * *} \\
(10.510)\end{array}$ & $\begin{array}{r}95.351^{* * *} \\
(7.236)\end{array}$ & $\begin{array}{r}86.181^{* \star *} \\
(4.793)\end{array}$ & $\begin{array}{r}-116.184^{* \star *} \\
(12.465)\end{array}$ \\
\hline Dummy 1999 & $\begin{array}{r}8.808 \\
(15.191)\end{array}$ & $\begin{array}{r}173.532^{* * *} \\
(11.279)\end{array}$ & $\begin{array}{r}83.419^{* * *} \\
(7.761)\end{array}$ & $\begin{array}{r}87.947^{* \star *} \\
(5.144)\end{array}$ & $\begin{array}{r}-164.692^{* * *} \\
(13.376)\end{array}$ \\
\hline Dummy 2000 & $\begin{array}{r}16.726 \\
(16.248)\end{array}$ & $\begin{array}{r}178.744^{* \star *} \\
(12.064)\end{array}$ & $\begin{array}{r}104.517^{* * *} \\
(8.301)\end{array}$ & $\begin{array}{r}73.276^{* \star *} \\
(5.501)\end{array}$ & $\begin{array}{r}-157.337^{* \star *} \\
(14.309)\end{array}$ \\
\hline Dummy 2001 & $\begin{array}{r}-27.720 \\
(17.365)\end{array}$ & $\begin{array}{r}166.688^{\star \star \star} \\
(12.894)\end{array}$ & $\begin{array}{r}94.966^{\star \star \star} \\
(8.871)\end{array}$ & $\begin{array}{r}78.116^{* * *} \\
(5.882)\end{array}$ & $\begin{array}{r}-189.890^{\star * *} \\
(15.295)\end{array}$ \\
\hline PFL & $\begin{array}{r}28.142^{\star * *} \\
(10.845)\end{array}$ & $\begin{array}{r}3.279 \\
(8.053)\end{array}$ & $\begin{array}{r}-5.273 \\
(5.538)\end{array}$ & $\begin{array}{l}6.443^{*} \\
(3.668)\end{array}$ & $\begin{array}{r}21.368^{* *} \\
(9.548)\end{array}$ \\
\hline PPB / PDS & $\begin{array}{r}9.332 \\
(11.444)\end{array}$ & $\begin{array}{r}3.583 \\
(8.498)\end{array}$ & $\begin{array}{r}1.180 \\
(5.846)\end{array}$ & $\begin{array}{l}8.913^{* *} \\
(3.871)\end{array}$ & $\begin{array}{r}3.545 \\
(10.076)\end{array}$ \\
\hline PMDB & $\begin{array}{r}10.614 \\
(11.003)\end{array}$ & $\begin{array}{r}0.848 \\
(8.170)\end{array}$ & $\begin{array}{r}-4.346 \\
(5.619)\end{array}$ & $\begin{array}{l}8.299^{* *} \\
(3.721)\end{array}$ & $\begin{array}{r}8.181 \\
(9.688)\end{array}$ \\
\hline PSDB & $\begin{array}{r}14.370 \\
(11.899)\end{array}$ & $\begin{array}{r}0.642 \\
(8.836)\end{array}$ & $\begin{array}{l}-1.301 \\
(6.079)\end{array}$ & $\begin{array}{r}6.001 \\
(4.025)\end{array}$ & $\begin{array}{r}10.469 \\
(10.478)\end{array}$ \\
\hline PTB & $\begin{array}{r}29.257^{\star * *} \\
(11.238)\end{array}$ & $\begin{array}{r}7.797 \\
(8.344)\end{array}$ & $\begin{array}{r}1.744 \\
(5.739)\end{array}$ & $\begin{array}{l}9.389^{* *} \\
(3.801)\end{array}$ & $\begin{array}{l}15.375 \\
(9.893)\end{array}$ \\
\hline OUTROS & $\begin{array}{r}30.434^{\star * *} \\
(10.883)\end{array}$ & $\begin{array}{r}4.145 \\
(8.081)\end{array}$ & $\begin{array}{r}-0.381 \\
(5.558)\end{array}$ & $\begin{array}{l}6.389^{*} \\
(3.681)\end{array}$ & $\begin{array}{r}23.718^{* *} \\
(9.581)\end{array}$ \\
\hline $\begin{array}{l}\text { Prefeito e } \\
\text { Governador }\end{array}$ & $\begin{array}{r}17.408^{\star \star *} \\
(5.043)\end{array}$ & $\begin{array}{l}6.230^{*} \\
(3.744)\end{array}$ & $\begin{array}{r}3.096 \\
(2.580)\end{array}$ & $\begin{array}{r}0.211 \\
(1.706)\end{array}$ & $\begin{array}{r}10.463^{* *} \\
(4.443)\end{array}$ \\
\hline Idosos & $\begin{array}{r}-6.794^{* *} \\
(3.269)\end{array}$ & $\begin{array}{r}-5.704^{* *} \\
(2.427)\end{array}$ & $\begin{array}{r}1.381 \\
(1.669)\end{array}$ & $\begin{array}{r}3.516^{* \star *} \\
(1.108)\end{array}$ & $\begin{array}{l}-0.316 \\
(2.885)\end{array}$ \\
\hline Urbanização & $\begin{array}{r}-1.625^{* * *} \\
(0.415)\end{array}$ & $\begin{array}{r}-0.671^{* *} \\
(0.308)\end{array}$ & $\begin{array}{r}0.326 \\
(0.212)\end{array}$ & $\begin{array}{r}0.872^{* * *} \\
(0.140)\end{array}$ & $\begin{array}{r}-1.004^{* * *} \\
(0.365)\end{array}$ \\
\hline Jovens & $\begin{array}{l}-3.716^{*} \\
(2.090)\end{array}$ & $\begin{array}{l}3.668^{\star *} \\
(1.552)\end{array}$ & $\begin{array}{r}2.853^{* * *} \\
(1.067)\end{array}$ & $\begin{array}{r}2.144^{* * *} \\
(0.707)\end{array}$ & $\begin{array}{r}-5.952^{* * *} \\
(1.840)\end{array}$ \\
\hline População & $\begin{array}{l}38.072^{* *} \\
(16.639)\end{array}$ & $\begin{array}{r}-7.314 \\
(12.354)\end{array}$ & $\begin{array}{r}-20.773^{\star *} \\
(8.499)\end{array}$ & $\begin{array}{r}-41.012^{2 * \star} \\
(5.656)\end{array}$ & $\begin{array}{r}61.105^{* \star *} \\
(14.657)\end{array}$ \\
\hline Constante & $\begin{array}{r}16.127 \\
(175.724)\end{array}$ & $\begin{array}{r}203.187 \\
(130.475)\end{array}$ & $\begin{array}{c}160.834^{*} \\
(89.754)\end{array}$ & $\begin{array}{r}224.930^{* * *} \\
(59.680)\end{array}$ & $\begin{array}{r}-379.362^{* \star} \\
(154.843)\end{array}$ \\
\hline$R^{2}$ & 0.8458 & 0.7916 & 0.6554 & 0.1616 & 0.4529 \\
\hline Observações & 7267 & 7256 & 7244 & 7256 & 7256 \\
\hline Teste de Hausman & $\begin{array}{r}x^{2}=244.57 \\
\text { Prob }=0.00\end{array}$ & $\begin{array}{r}x^{2}=479.64 \\
\text { Prob }=0.00\end{array}$ & $\begin{array}{r}x^{2}=372.56 \\
\text { Prob }=0.00\end{array}$ & $\begin{array}{r}x^{2}=198.76 \\
\text { Prob }=0.00\end{array}$ & $\begin{array}{r}x^{2}=100.11 \\
\text { Prob }=0.00\end{array}$ \\
\hline
\end{tabular}


Tabela 10 - Resultados das regressões - receita de transferências governamentais - teste da LRF - método de efeitos fixos

\begin{tabular}{|c|c|c|c|c|c|}
\hline & $\begin{array}{c}\text { Despesa } \\
\text { orçamentária }\end{array}$ & $\begin{array}{l}\text { Despesa } \\
\text { corrente }\end{array}$ & $\begin{array}{c}\text { Despesa de } \\
\text { pessoal }\end{array}$ & $\begin{array}{c}\text { Transferências } \\
\text { correntes }\end{array}$ & Investimentos \\
\hline $\begin{array}{l}\text { Receita de } \\
\text { transferências }\end{array}$ & $\begin{array}{l}1.037^{\star \star \star} \\
(0.009)\end{array}$ & $\begin{array}{l}0.622^{* \star \star} \\
(0.006)\end{array}$ & $\begin{array}{l}0.278^{\star \star *} \\
(0.005)\end{array}$ & $\begin{array}{l}0.095^{\star \star *} \\
(0.003)\end{array}$ & $\begin{array}{l}0.389^{* * *} \\
(0.008)\end{array}$ \\
\hline Dummy LRF & $\begin{array}{c}-54.663^{* * *} \\
(4.691)\end{array}$ & $\begin{array}{c}-26.022^{* * *} \\
(3.511)\end{array}$ & $\begin{array}{l}-2.271 \\
(2.416)\end{array}$ & $\begin{array}{c}1.962 \\
(1.711)\end{array}$ & $\begin{array}{c}-23.933^{\star * *} \\
(4.128)\end{array}$ \\
\hline PFL & $\begin{array}{l}31.115^{\star \star *} \\
(11.286)\end{array}$ & $\begin{array}{c}6.027 \\
(8.447)\end{array}$ & $\begin{array}{l}-3.761 \\
(5.809)\end{array}$ & $\begin{array}{l}9.011^{\text {** }} \\
(4.112)\end{array}$ & $\begin{array}{l}21.772^{* *} \\
(9.908)\end{array}$ \\
\hline PPB / PDS & $\begin{array}{c}16.225 \\
(11.907)\end{array}$ & $\begin{array}{c}7.039 \\
(8.911)\end{array}$ & $\begin{array}{c}2.163 \\
(6.130)\end{array}$ & $\begin{array}{l}8.903^{* *} \\
(4.338)\end{array}$ & $\begin{array}{c}6.896 \\
(10.453)\end{array}$ \\
\hline PMDB & $\begin{array}{l}35.191^{* * *} \\
(11.352)\end{array}$ & $\begin{array}{l}15.297^{*} \\
(8.496)\end{array}$ & $\begin{array}{l}-0.713 \\
(5.843)\end{array}$ & $\begin{array}{c}1.495 \\
(4.136)\end{array}$ & $\begin{array}{l}17.480^{*} \\
(9.966)\end{array}$ \\
\hline PSDB & $\begin{array}{l}28.189^{* *} \\
(12.211)\end{array}$ & $\begin{array}{l}29.920^{* * *} \\
(9.138)\end{array}$ & $\begin{array}{l}18.154^{* * *} \\
(6.288)\end{array}$ & $\begin{array}{l}11.109^{* *} \\
(4.449)\end{array}$ & $\begin{array}{c}-6.062 \\
(10.721)\end{array}$ \\
\hline PTB & $\begin{array}{l}31.623^{* * *} \\
(11.705)\end{array}$ & $\begin{array}{c}8.246 \\
(8.759)\end{array}$ & $\begin{array}{c}1.637 \\
(6.026)\end{array}$ & $\begin{array}{l}11.126^{* * *} \\
(4.265)\end{array}$ & $\begin{array}{r}17.635^{\star} \\
(10.275)\end{array}$ \\
\hline OUTROS & $\begin{array}{l}36.431^{* * *} \\
(11.326)\end{array}$ & $\begin{array}{c}5.257 \\
(8.476)\end{array}$ & $\begin{array}{l}-0.856 \\
(5.831)\end{array}$ & $\begin{array}{c}4.631 \\
(4.127)\end{array}$ & $\begin{array}{l}28.468^{\star \star *} \\
(9.943)\end{array}$ \\
\hline $\begin{array}{l}\text { Prefeito \& } \\
\text { Governador }\end{array}$ & $\begin{array}{l}-3.471 \\
(4.886)\end{array}$ & $\begin{array}{c}-17.464^{* \star *} \\
(3.657)\end{array}$ & $\begin{array}{l}-8.815^{\star \star *} \\
(2.520)\end{array}$ & $\begin{array}{c}3.147^{*} \\
(1.781)\end{array}$ & $\begin{array}{l}14.338^{* * *} \\
(4.293)\end{array}$ \\
\hline Idosos & $\begin{array}{l}11.358^{* * *} \\
(3.199)\end{array}$ & $\begin{array}{l}2.916 \\
(2.394)\end{array}$ & $\begin{array}{l}4.630^{* * *} \\
(1.647)\end{array}$ & $\begin{array}{l}-6.525^{* * *} \\
(1.168)\end{array}$ & $\begin{array}{l}9.039^{* * *} \\
(2.814)\end{array}$ \\
\hline Urbanização & $\begin{array}{l}-1.459^{* * *} \\
(0.410)\end{array}$ & $\begin{array}{l}0.943^{* * *} \\
(0.307)\end{array}$ & $\begin{array}{l}1.211^{* * *} \\
(0.211)\end{array}$ & $\begin{array}{l}1.542^{* * *} \\
(0.150)\end{array}$ & $\begin{array}{l}-2.456^{* \star *} \\
(0.360)\end{array}$ \\
\hline Jovens & $\begin{array}{l}-3.456^{\star \star \star} \\
(1.069)\end{array}$ & $\begin{array}{c}-18.080^{\star \star \star} \\
(0.800)\end{array}$ & $\begin{array}{l}-9.172^{* * *} \\
(0.551)\end{array}$ & $\begin{array}{l}-9.691^{* * *} \\
(0.390)\end{array}$ & $\begin{array}{l}16.110^{* * *} \\
(0.939)\end{array}$ \\
\hline População & $\begin{array}{l}68.866^{* \star *} \\
(15.585)\end{array}$ & $\begin{array}{l}88.098^{\star * \star} \\
(11.663)\end{array}$ & $\begin{array}{l}29.801^{* * *} \\
(8.024)\end{array}$ & $\begin{array}{c}-15.296^{* * *} \\
(5.703)\end{array}$ & $\begin{array}{c}-3.948 \\
(13.693)\end{array}$ \\
\hline Constante & $\begin{array}{l}-372.313^{* *} \\
(180.401)\end{array}$ & $\begin{array}{l}-149.982 \\
(135.004)\end{array}$ & $\begin{array}{l}-12.021 \\
(92.883)\end{array}$ & $\begin{array}{l}358.180^{* \star *} \\
(65.978)\end{array}$ & $\begin{array}{l}-409.574^{* \star \star} \\
(158.491)\end{array}$ \\
\hline$R^{2}$ & 0.8393 & 0.5783 & 0.5320 & 0.3242 & 0.2726 \\
\hline Observações & 7267 & 7265 & 7244 & 7256 & 7256 \\
\hline Teste de Hausman & $\begin{array}{l}x^{2}=169.31 \\
\text { Prob }=0.00\end{array}$ & $\begin{array}{r}x^{2}=516.27 \\
\text { Prob }=0.00\end{array}$ & $\begin{array}{l}x^{2}=256.92 \\
\text { Prob }=0.00\end{array}$ & $\begin{array}{r}x^{2}=416.03 \\
\text { Prob }=0.00\end{array}$ & $\begin{array}{r}x^{2}=236.22 \\
\text { Prob }=0.00\end{array}$ \\
\hline
\end{tabular}

